\title{
Development of $\left(\mathrm{Mn}_{0.77} \mathrm{Fe}_{0.23}\right)_{2} \mathrm{O}_{3}$ Particles as an Oxygen Carrier for Coal Combustion with $\mathrm{CO}_{2}$ capture via in-situ Gasification Chemical Looping Combustion (iG-CLC) aided by Oxygen Uncoupling (CLOU)
}

\author{
R. Pérez-Vega, A. Abad*, P. Gayán, L.F. de Diego, F. García-Labiano, J. Adánez \\ Department of Energy and Environment, Instituto de Carboquímica (ICB-CSIC), \\ Miguel Luesma Castán, 4, Zaragoza, 50018, Spain
}

*Corresponding author:

Phone: + 34 976733977. Fax: +34 976733318. E-mail: abad@icb.csic.es (Alberto Abad)

\begin{abstract}
Chemical Looping Combustion (CLC) involves the use of a solid oxygen carrier to transport the oxygen from the air to a fuel. Attention has recently been focused on oxygen carriers based on Mn-Fe mixed oxides because they are cheap materials that are able to release oxygen at high temperature, the so-called oxygen uncoupling step. The aim of this work was to assess the use of $\left(\mathrm{Mn}_{0.77} \mathrm{Fe}_{0.23}\right)_{2} \mathrm{O}_{3}$ material as an oxygen carrier with the ability to transport oxygen both by reduction with gaseous fuels and by oxygen uncoupling, i.e. typical mechanisms in CLC and in Chemical Looping with Oxygen Uncoupling (CLOU), respectively. The particles prepared by mechanical mixing were screened to obtain particles of sufficient reactivity and mechanical strength for use in a fluidized bed
\end{abstract}


reactor. The preparation methodology and calcining temperature were varied. The reactivity of one selected material was evaluated by performing redox cycles both in a TGA and a batch fluidized-bed reactor. Thus, its behaviour was assessed during both decompositionregeneration of bixbyite phase $\left[\left(\mathrm{Mn}_{0.77} \mathrm{Fe}_{0.23}\right)_{2} \mathrm{O}_{3}\right]$ in CLOU and the reduction-oxidation of spinel phase $\left[\left(\mathrm{Mn}_{0.77} \mathrm{Fe}_{0.23}\right)_{3} \mathrm{O}_{4}\right]$ with gaseous fuels, i.e. $\mathrm{H}_{2}, \mathrm{CO}$ and $\mathrm{CH}_{4}$. Its oxygen uncoupling and re-oxidation capability was highly influenced by the reaction temperature and oxygen concentration. On the other hand, CLC redox cycles with gaseous fuels showed high reactivity with $\mathrm{H}_{2}$ and $\mathrm{CO}$ and high oxygen transport capacity by reduction to mangano-wüstite phase [( $\left.\left.\mathrm{Mn}_{0.77} \mathrm{Fe}_{0.23}\right) \mathrm{O}\right]$. Good fluid-dynamic behaviour was observed for the oxygen carrier particles along the redox cycles without agglomeration problems, regardless of the operating conditions used in the batch fluidized-bed reactor. Thus, the selected material was considered a promising candidate for use in both in CLC with syngas and CLC with coal.

Keywords: $\mathrm{CO}_{2}$ capture; Chemical Looping Combustion (CLC); Chemical Looping with Oxygen Uncoupling (CLOU); Oxygen Carriers; Manganese Oxides; Iron Oxides.

\section{Introduction}

Chemical Looping Combustion (CLC) is a promising technology that is able to capture $\mathrm{CO}_{2}$ at low cost and with a low energy penalty in the power generation process [1]. CLC is based on the transfer of oxygen from the air to the fuel by means of a solid oxygen carrier. In the most common configuration, the oxygen carrier is continuously circulated between two interconnected fluidized-bed reactors, known as the fuel and air reactors [2]. 
The development of Chemical Looping technology for solid fuel combustion has made an important advance over the last decade by means of two processes: in-situ Gasification (iGCLC) and Oxygen Uncoupling (CLOU) [1,2]. The iG-CLC concept works by supplying steam and/or recycled $\mathrm{CO}_{2}$ to the fuel reactor as gasifying agents. In-situ gasification of solid fuel (e.g. coal) takes place inside the fuel reactor, as does the subsequent oxidation of the gasification products by gas-solid reactions with the oxygen carrier. Unburnt products, such as $\mathrm{H}_{2}, \mathrm{CO}$ and $\mathrm{CH}_{4}$, are usually found in existing $i \mathrm{G}-\mathrm{CLC}$ facilities. The CLOU concept uses a metal oxide with the ability to release gaseous oxygen in the fuel reactor $[3,4]$. The solid fuel is subsequently burnt with the gaseous oxygen, avoiding the slow gasification step. Solid fuel conversion by CLOU is thus improved, compared to $i \mathrm{G}-\mathrm{CLC}$ $[5,6]$.

Low cost materials based on iron or manganese ores have mostly been used as oxygen carriers in $i$ G-CLC $[1,2]$, while synthetic materials based on copper and manganese are being developed for CLOU [7,8]. Cu-based materials were primarily developed because of their high reactivity. The development of Mn-based materials as oxygen carriers in CLOU has recently become the focus of attention because they are cheaper than those made with copper. In recent years, there has been great interest in the use of mixed oxides of manganese and iron as oxygen carriers due to their potential use in CLOU mode. The thermodynamics of the $\mathrm{Mn}-\mathrm{Fe}-\mathrm{O}$ system have been studied for decades and are being revised periodically with new experimental findings [9]. Phase equilibrium diagrams for the $\mathrm{Mn}-\mathrm{Fe}-\mathrm{O}$ system are replicated in Figure 1 using FactSage ${ }^{\mathrm{TM}}$ software, and show stable phases as a function of temperature and the oxygen partial pressure. The temperature and oxygen partial pressure values required for transformation between bixbyite phase, i.e. 
$\left(\mathrm{Mn}_{\mathrm{x}} \mathrm{Fe}_{1-\mathrm{x}}\right)_{2} \mathrm{O}_{3}$, and spinel phase, i.e. $\left(\mathrm{Mn}_{\mathrm{x}} \mathrm{Fe}_{1-\mathrm{x}}\right)_{3} \mathrm{O}_{4}$, are suitable for use in the CLOU process; see reaction $\mathrm{R} 3$.

$3\left(\mathrm{Mn}_{\mathrm{x}} \mathrm{Fe}_{1-\mathrm{x}}\right)_{2} \mathrm{O}_{3} \leftrightarrow 2\left(\mathrm{Mn}_{\mathrm{x}} \mathrm{Fe}_{1-\mathrm{x}}\right)_{3} \mathrm{O}_{4}+0.5 \mathrm{O}_{2}$

This property has been exploited for the design of a relevant number of oxygen carrier materials [10]. Thus, oxidation conditions must allow oxidation to bixbyite [11-14]. According to Larring et al., the optimum operating temperature should be evaluated depending on the Mn:Fe ratio and the existing $\mathrm{O}_{2}$ partial pressure [11]. For example, considering oxidation in air, the transition temperature between spinel and bixbyite varies from $970{ }^{\circ} \mathrm{C}$ for Mn-rich materials to $1030^{\circ} \mathrm{C}$ for Fe-rich materials; see Figure 1(a). But transition temperatures are $70{ }^{\circ} \mathrm{C}$ lower if the oxygen partial pressure is 0.05 atm. Nevertheless, the oxygen uncoupling ability is facilitated by using Mn-rich materials owing to the narrow gap between bixbyite and spinel phases; see Figure 1(a) [13-15]. Also, conversion to bixbyite will be determined by reaction kinetics, which usually increases with temperature [16]. However, it should be taken into consideration that the increase in temperature increases the oxygen concentration necessary to reach bixbyite phase [11].

With regard to the oxygen transfer from bixbyite, both the oxygen uncoupling mechanism and reactivity with fuel gases must be considered. $\left(\mathrm{Mn}_{\mathrm{x}} \mathrm{Fe}_{1-\mathrm{x}}\right)_{2} \mathrm{O}_{3}$ materials showed oxygen uncoupling at $850{ }^{\circ} \mathrm{C}$ for the stoichiometric parameter $\mathrm{x}>0.5$, whereas the optimum temperature was $900-950{ }^{\circ} \mathrm{C}$ for materials with $\mathrm{x} \leq 0.4$ [13]. By way of example, Figure 1(b) shows the phase diagram as a function of oxygen partial pressure and temperature for the $\mathrm{Mn} /(\mathrm{Mn}+\mathrm{Fe})$ atomic ratio of 0.8 . Under fuel reactor conditions, the transition from bixbyite to spinel can be driven by the oxygen uncoupling mechanism. 
In addition to its oxygen uncoupling capability, bixbyite can be reduced by fuel gases such as $\mathrm{H}_{2}, \mathrm{CO}$ and $\mathrm{CH}_{4}$, and spinel can then be reduced to mangano-wüstite $\left(\mathrm{Mn}_{\mathrm{x}} \mathrm{Fe}_{1-\mathrm{x}} \mathrm{O}\right)$, as shown in Figure 1(b); see reactions R2 and R3 for reduction with $\mathrm{H}_{2} . \mathrm{MnO}$ and $\mathrm{Fe}_{3} \mathrm{O}_{4}$ have also been reported as final products after reduction with 5 vol.\% $\mathrm{CH}_{4}$ or coal $[17,18]$. Further reduction to metallic Fe is also possible $[19,20]$, but this would be not desirable because thermodynamic restrictions prevent complete combustion to $\mathrm{CO}_{2}$ and $\mathrm{H}_{2} \mathrm{O}$.

$3\left(\mathrm{Mn}_{\mathrm{x}} \mathrm{Fe}_{1-\mathrm{x}}\right)_{2} \mathrm{O}_{3}+\mathrm{H}_{2} \rightarrow 2\left(\mathrm{Mn}_{\mathrm{x}} \mathrm{Fe}_{1-\mathrm{x}}\right)_{3} \mathrm{O}_{4}+\mathrm{H}_{2} \mathrm{O}$

$\left(\mathrm{Mn}_{\mathrm{x}} \mathrm{Fe}_{1-\mathrm{x}}\right)_{3} \mathrm{O}_{4}+\mathrm{H}_{2} \rightarrow 3 \mathrm{Mn}_{\mathrm{x}} \mathrm{Fe}_{1-\mathrm{x}} \mathrm{O}+\mathrm{H}_{2} \mathrm{O}$

Most of the synthetized Mn-Fe oxygen carriers were tested with gaseous fuels and showed good behaviour during syngas combustion, reaching fuel conversions close to $100 \%$. Furthermore, some $\mathrm{Mn}-\mathrm{Fe}$ materials allowed high $\mathrm{CH}_{4}$ conversion when the material was checked under a suitable reaction temperature $[13,16]$. In general, reactivity with fuel gases increased with $\mathrm{Mn}$ content $[11,12,16,21]$. Thus, $\left(\mathrm{Mn}_{\mathrm{x}} \mathrm{Fe}_{1-\mathrm{x}}\right)_{2} \mathrm{O}_{3}$ materials with $\mathrm{x}>0.5$ showed high reactivity against $\mathrm{CH}_{4}$ at $850^{\circ} \mathrm{C}[13]$.

It is worth noting that the theoretical oxygen transport capacity available for the oxygen uncoupling reaction (bixbyite to spinel) is $R_{O C}^{o u}=3.3 \mathrm{wt} . \%$, while the reduction of bixbyite to mangano-wüstite offers a theoretical oxygen transport capacity of $R_{O C}^{t}=10.1 \mathrm{wt} . \%$. Reduction to mangano-wüstite can be exploited in the use of Mn-Fe materials for solid fuel combustion in the $i \mathrm{G}-\mathrm{CLC}$ mode. However, few Mn-Fe materials have been tested in a CLC unit. Pérez-Vega et al. [22] tested a Mn-Fe material in a coal-fired CLC unit. Both $\mathrm{CO}_{2}$ capture and combustion efficiency were improved compared to results obtained with ilmenite. Thus, by transferring a fraction of the oxygen via the oxygen uncoupling mechanism, combustion efficiency could be improved, compared to common Fe- or Mn- 
based materials without oxygen uncoupling characteristics. In another work, Rydén et al. [23] obtained high $\mathrm{CH}_{4}$ conversion in a $300 \mathrm{~W}$ CLC unit using particles prepared by spray drying with a $\mathrm{Mn}: \mathrm{Fe}=1: 2$ molar ratio. However, mechanical strength was low and a relevant fraction of particles became dust after $4 \mathrm{~h}$ of operation.

From previous works, we can infer that the oxygen uncoupling capability of combined MnFe oxides can be exploited under the proper conditions. However, their regeneration capability has not been studied in detail. Moreover, the subsequent reduction of spinel with fuel gases requires further analysis, because a significant amount of oxygen in the combustion of coal could be transferred by solid-gas reactions [22]. It is therefore of interest to analyse both of the oxygen transfer processes involved to allow the conversion of coal by combining in-situ gasification and oxygen uncoupling.

The aim of this work was to develop a Mn-Fe mixed oxide material as an oxygen carrier with oxygen transport capability both for oxygen uncoupling and reduction by a fuel, which could be used in CLC with coal assisted by oxygen uncoupling (CLaOU). The composition $\left(\mathrm{Mn}_{0.77} \mathrm{Fe}_{0.23}\right)_{2} \mathrm{O}_{3}$ was fixed because materials with more $\mathrm{Mn}$ are generally more reactive, and because the gap between bixbyite and spinel phases is minimized with this composition; see Figure 1(a). A screening of the preparation methodology of $\left(\mathrm{Mn}_{0.77} \mathrm{Fe}_{0.23}\right)_{2} \mathrm{O}_{3}$ particles by mechanical mixing was performed with the target of producing highly reactive particles with enough strength for a fluidized bed operation. Oxygen transport capacity, reaction rate and mechanical strength were evaluated for the purpose of selecting an optimal Mn-Fe-based oxygen carrier. The reactivity behaviour against different gaseous fuels and the fluid-dynamic properties of the selected material were analysed in a fluidized bed reactor. 


\section{Experimental}

\subsection{Preparation of materials}

Ten different materials were prepared by mechanical mixing of precursor powders to screen for the Mn-Fe based oxygen carriers. Table 1 shows a summary of the oxygen carriers manufactured together with their main physical properties. Most of the particles were prepared using $\mathrm{Mn}_{3} \mathrm{O}_{4}$ (Strem Chemical Inc.) and $\mathrm{Fe}_{2} \mathrm{O}_{3}$ (Panreac Prs.) powders. In one case, $\mathrm{MnO}_{2}$ (Sigma-Aldrich) powder was used as the Mn source instead of $\mathrm{Mn}_{3} \mathrm{O}_{4}$. The atomic Mn:Fe ratio was set to 77:23, except for Mn60Fe[L4] for which the ratio was 60:40 in order to evaluate the effect of the $\mathrm{Mn}$ :Fe ratio on particle properties. Moreover, some materials were produced with addition of graphite (Sigma-Aldrich) or kaolin (SYCA S.L.) with the purpose of increasing the porosity or mechanical strength of the particles, respectively.

Raw materials at the desired fractions were mixed in a ball mill. The milling process was modified in order to obtain three batches of solids with different particle size distribution. Thus, mean particle sizes of $5 \mu \mathrm{m}$ and $2.6 \mu \mathrm{m}$ were obtained with milling times of 20 and 90 min, respectively. To obtain a lower mean particle size $(1.9 \mu \mathrm{m})$, a method adapted from the ferrites manufacturing process was used [24]. The solids mixture was calcined for 4 hours at $1050^{\circ} \mathrm{C}$, and the calcined solid was subsequently milled for 300 minutes. Particles identified as $[\mathrm{L}],[\mathrm{M}]$ or $[\mathrm{S}]$ in Table 1 means that the particle size of the powder used as a precursor of the oxygen carrier was $5 \mu \mathrm{m}, 2.6 \mu \mathrm{m}$ or $1.9 \mu \mathrm{m}$, respectively. 
After the mixing step, cylindrical pellets (10 $\mathrm{mm}$ diameter, $15 \mathrm{~mm}$ height) were produced by pressure at $16 \mathrm{MPa}$, which were calcined for different times $(2-18 \mathrm{~h})$ at $950{ }^{\circ} \mathrm{C}$. In some cases, an additional calcination step was performed at $1100{ }^{\circ} \mathrm{C}$ for $2 \mathrm{~h}$. Eventually, pellets were crushed and sieved to obtain the desired particle diameter $(+100-300 \mu \mathrm{m})$.

\subsection{Characterization of the particles}

Mechanical strength was determined using a Shimpo FGN-5X crushing strength apparatus. It took an average value of 20 measurements of the force needed to fracture a particle. Skeletal density was measured with a Micromeritics AccuPyc II 1340 helium pycnometer. Particle porosity was measured by $\mathrm{Hg}$ intrusion in a Quantachrome PoreMaster 33 . Identification of the crystalline chemical species was carried out by X-ray diffraction (XRD) difractogram collected by a Bruker D8 Advance X-ray powder diffractometer equipped with an X-ray source with a $\mathrm{Cu}$ anode working at $40 \mathrm{kV}$ and $40 \mathrm{~mA}$ and an energy-dispersive one-dimensional detector.

\subsection{Thermogravimetric analyser}

The oxygen transport capacity $\left(R_{O C}\right)$ and reaction rates of the materials were determined in a thermogravimetric analyser (TGA), CI Electronics type. A detailed description of the apparatus has already been reported elsewhere [25]. In all experiments, about $50 \mathrm{mg}$ of sample were introduced into a platinum basket hanging inside a quartz reactor. The sample was initially heated in air up to the desired reacting temperature.

To analyse the oxygen uncoupling properties due to reaction from bixbyite to spinel phases, decomposition-regeneration cycles were performed alternating highly-pure $\mathrm{N}_{2}(<2 \mathrm{ppm}$ $\mathrm{O}_{2}$ ) and air at temperatures in the $800-920{ }^{\circ} \mathrm{C}$ interval. During the stage in $\mathrm{N}_{2}$, reduction to spinel was guaranteed; see Figure 1(b). In addition, oxygen concentration values between 5 
and 21 vol.\% were used during the oxidation period to evaluate the ability to regenerate bixbyite.

Reduction of bixbyite with gaseous fuels $\left(\mathrm{H}_{2}, \mathrm{CO}\right.$ and $\left.\mathrm{CH}_{4}\right)$ was evaluated by performing redox cycles that alternated reducing and oxidizing conditions at $950{ }^{\circ} \mathrm{C}$ in order to compare the reactivity of MnFe materials with that of other materials used as oxygen carriers in $i \mathrm{G}-\mathrm{CLC}$ (e.g. ilmenite, iron ore, etc.). $\mathrm{H}_{2} \mathrm{O}$ or $\mathrm{CO}_{2}$ was used in the reacting mixture to prevent the formation of $\mathrm{FeO}$ or $\mathrm{Fe}$, which would be undesirable if complete fuel conversion is to be achieved.

\subsection{Batch fluidized-bed reactor}

A batch fluidized-bed reactor was used to assess the oxygen carrier's performance in terms of reactivity and agglomeration at similar conditions to those existing in a CLC unit. A mass of $350 \mathrm{~g}$ oxygen carrier was used. Information regarding the experimental setup can be found elsewhere [26], including the feeding system for reacting gases, the reactor system, and the gas analysers to determine the concentration of gases at the reactor outlet. The concentration vs time curves obtained during the experiments were corrected by means of a deconvolution method in order to correct dispersion and delay effects, thus obtaining the actual concentration at the batch fluidized-bed exit.

The oxygen uncoupling capability of material was evaluated by alternating air and $\mathrm{N}_{2}(300$ $\mathrm{L}_{\mathrm{N}} / \mathrm{h}$ ) at 800,850 and $900{ }^{\circ} \mathrm{C}$. In addition, some redox cycles were carried out at $900{ }^{\circ} \mathrm{C}$ using diluted air (5 and $10 \mathrm{vol} \% \mathrm{O}_{2}$ ) during the oxidation period to evaluate the regenerability of the material.

Reduction by 50 vol. $\% \mathrm{H}_{2}, 50$ vol. $\% \mathrm{CO}$ or 25 vol.\% $\mathrm{CH}_{4}$ was analysed at 900 and $950{ }^{\circ} \mathrm{C}$.

The total gas flow was $600 \mathrm{~L}_{N} / \mathrm{h}$ for $\mathrm{H}_{2}$ and $\mathrm{CO}$, while $300 \mathrm{~L}_{N} / \mathrm{h}$ was used with $\mathrm{CH}_{4}$. In this 
way, the same oxygen requirement was required for the fuel combustion regardless of the gas used. Oxidation was performed by using 5 or 10 vol.\% $\mathrm{O}_{2}$.

\subsection{Data evaluation}

The normalized mass-loss variation $(\omega)$ represents the fraction of the actual mass of the oxygen carrier compared to the mass of oxidized particles. It was calculated as:

$$
\omega=\frac{m}{m_{o}}
$$

where $m$ is the instantaneous mass of the sample and $m_{o}$ the initial mass.

The oxygen transport capacity for the redox system $i\left(R_{O C}^{i}\right)$ is defined as the mass fraction of particles being used in the oxygen transference. A normalized $R_{O C}^{i}$ parameter was calculated as:

$$
R_{O C}^{i}=\frac{m_{o}^{i}-m_{r}^{i}}{m_{b i x}}
$$

where $m_{o}^{i}$ and $m_{r}^{i}$ are the mass of the sample after oxidation and reduction, respectively, while $m_{b i x}$ is the mass of the sample, assuming that it was fully oxidized to bixbyite. Note that $m_{o}^{i}<m_{b i x}$ if the sample is partially oxidized. $R_{O C}^{o u}$ is defined for bixbyite reduction to spinel; see reaction R2. However, for reduction with a fuel gas, e.g. $\mathrm{H}_{2}, R_{O C}^{g}$ is defined for reduction of spinel phase to mangano-wüstite; see reactions R3. The accumulated or total mass loss from bixbyite to mangano-wüstite is defined by $R_{O C}^{t}=R_{O C}^{o u}+R_{O C}^{g}$.

The reduction $\left(X_{r}^{i}\right)$ and oxidation $\left(X_{o}^{i}\right)$ conversions corresponding to either oxygen uncoupling $(i=o u)$, reduction by gas fuel $(i=g)$, or total reduction from bixbyite to manganowüstite $(i=t)$ were calculated from the mass variations in TGA as: 


$$
\begin{gathered}
X_{r}^{i}=\frac{m_{o}^{i}-m}{R_{O C}^{i} \cdot m_{b i x}} \\
X_{o}^{i}=\frac{m-m_{r}^{i}}{R_{O C}^{i} \cdot m_{b i x}}
\end{gathered}
$$

The reactivity of the materials was evaluated by calculating the normalized Rate index [27] which is normalized to a reference partial pressure of the fuel gas, $P_{r e f}$, considering the reaction rate obtained at the partial pressure in TGA, $P_{T G A}$ :

Rate index $(\% / \mathrm{min})=60 \cdot 100 \cdot R_{O C}^{i} \frac{P_{r e f}}{P_{T G A}}\left(\frac{d X_{j}^{i}}{\mathrm{~d} t}\right)_{T G A}$

$P_{\text {ref }}$ was set to 0.15 atm for the reduction, and to 0.10 atm for the oxidation.

In the fluidized bed reactor, the oxygen transfer rate as function of time, $r_{O}(t)$, during fuel combustion and oxidation periods was calculated as:

Reduction: $\quad r_{O}(t)=\left(\gamma_{\mathrm{CO}}+2 \gamma_{\mathrm{CO}_{2}}+\gamma_{\mathrm{H}_{2} \mathrm{O}}\right)_{\text {out }} \cdot F_{\text {out }}-\left(\gamma_{\mathrm{CO}}+2 \gamma_{\mathrm{CO}_{2}}+\gamma_{\mathrm{H}_{2} \mathrm{O}}\right)_{\text {in }} \cdot F_{\text {in }}$

Oxidation: $\quad r_{O}(t)=-\left[2\left(\gamma_{O_{2}}\right)_{\text {out }} \cdot F_{\text {out }}-2\left(\gamma_{O_{2}}\right)_{\text {in }} \cdot F_{\text {in }}\right]$

where $\gamma_{g}$ is the molar fraction of gas $g$, and $F_{\text {in }}$ and $F_{\text {out }}$ are the molar gas flow at the reactor inlet and outlet, respectively. The oxygen carrier conversion $X_{o}^{g}$ was then calculated for the reduction and oxidation steps as:

Reduction: $\quad X_{o}^{g}\left(t_{r}\right)=1-\frac{M_{O}}{m_{O C} \cdot R_{O C}^{g}} \int_{0}^{t} r_{O}(t) \cdot d t$

Oxidation: $\quad X_{o}^{g}\left(t_{o}\right)=X_{o}^{g}\left(t_{r, \max }\right)+\frac{M_{O}}{m_{O C} \cdot R_{O C}^{g}} \int_{0}^{t} r_{O}(t) \cdot d t$

where $m_{O C}$ is the mass of the fully oxidized oxygen carrier and $M_{O}$ the oxygen atomic mass. 


\section{Results}

\subsection{Screening of Mn-Fe based oxygen carriers}

Table 1 shows the main physical characteristics of the prepared materials. Interestingly, bixbyite was formed after a calcination step. The screening of Mn-Fe based oxygen carriers was carried out by means of comparing the crushing strength, oxygen transport capacity and Rate index values, both for reduction and oxygen uncoupling. The crushing strength value, although quite simple and insufficient to evaluate the stress suffered by particles in a CLC unit, had been identified as a useful parameter in the initial screening stages [28]. Oxygen transport capacity and the Rate index values were obtained through experiments performed in a TGA apparatus consisting of four consecutive redox cycles. Stable reactivity is usually observed in the third redox cycle; thus, the results obtained during the third redox cycle were used in this work.

Oxygen uncoupling capability was evaluated from decomposition-regeneration of the bixbyite phase by alternating highly-pure $\mathrm{N}_{2}$ and air at $870{ }^{\circ} \mathrm{C}$. The inert period lasted 30 min. Bixbyite decomposition was initially fast, but it slowed down before the reaction was completed. Thus, the mass loss in $\mathrm{N}_{2}$ was lower than the theoretical values of $R_{O C}^{o u}=3.4$ wt.\% for reaction R1; see Table 2. Full decomposition of bixbyite phase was not achieved, with conversion values to spinel recorded in the $62-94 \%$ interval.

Reactivity with a reducing gas was evaluated by performing redox cycles at $950{ }^{\circ} \mathrm{C}$, alternating 5 vol. $\% \mathrm{H}_{2}+40$ vol. $\% \mathrm{H}_{2} \mathrm{O}\left(\mathrm{N}_{2}\right.$ to balance) for the reducing period and air in the oxidized step. For example, Figure 2 shows the evolution of the normalized mass-loss with time during redox cycles with $\mathrm{H}_{2}$ using Mn77Fe[L4] particles. During the purge step, previous to the first reduction, a mass loss of $2.8 \mathrm{wt} . \%$ was recorded, corresponding to the 
oxygen uncoupling capability of these materials; see reaction R1 and Figure 1. The reduction of the spinel to mangano-wüstite with $\mathrm{H}_{2}$ subsequently took place by means of reactions $\mathrm{R} 2$ and $\mathrm{R} 3$. The accumulated mass loss from the initial bixbyite was 9.6 wt.\%. Considering that the theoretical mass loss value is $10.1 \mathrm{wt} . \%$, a $X_{r}^{t}$ value of $95 \%$ was calculated for Mn77Fe[L4] material.

During the subsequent period in air, oxidation was observed of mangano-wüstite phase to spinel phase, but regeneration to bixbyite phase was not possible. Therefore, the reoxidation of $\mathrm{Mn} 77 \mathrm{Fe}[\mathrm{L} 4]$ was ruled by:

$3 \mathrm{Mn}_{0.77} \mathrm{Fe}_{0.23} \mathrm{O}+0.5 \mathrm{O}_{2} \rightarrow\left(\mathrm{Mn}_{0.77} \mathrm{Fe}_{0.23}\right)_{3} \mathrm{O}_{4}$

It is worth noting that the oxidation rate greatly increased after the first redox cycle, while no major differences could be observed in the reduction stage. The mass variation during these cycles was found to be $6.6 \mathrm{wt} . \%$, very close to the theoretical value of $6.7 \mathrm{wt} . \%$. This fact agrees with the phase diagram for Mn-Fe mixed oxides, where spinel phase is thermodynamically stable at $950{ }^{\circ} \mathrm{C}$ in air; see Figures 1 .

The same redox cycles were repeated for all oxygen carrier materials synthetized in this work; see Table 1. A similar behaviour to that shown in Figure 2 was observed in all cases. Similar results were also obtained by Lambert et al. [16] during the reduction with $\mathrm{CH}_{4}$ at $900{ }^{\circ} \mathrm{C}$ in TGA. They concluded that materials with a Mn:Fe atomic ratio higher than $1: 1$ did not provide gas phase oxygen for CLOU, but that reduction from spinel to manganowüstite could be exploited for the $i \mathrm{G}-\mathrm{CLC}$ process.

For screening purposes, the oxygen transport capacity, Rate index and crushing strength values observed for the different materials are shown in Table 2. First, the effect of the raw material particle size was observed by comparing results obtained with Mn77Fe[L4], 
Mn77Fe[M4] and Mn77Fe[S4]. Interestingly, Mn77Fe[S4] particles showed the lowest mechanical strength and porosity values, which very distinct from those shown by Mn77Fe[L4] and Mn77Fe[M4]. This suggests that the different preparation methods used to obtain the finer powder could critically affect these properties.

With regard to oxygen transport capacity for oxygen uncoupling, the $R_{O C}^{o u}$ value decreased when finer particles were used in the raw materials. The lower $R_{O C}^{o u}$ value compared to the theoretical value for Mn77Fe[S4] may be related to its low porosity; see Table 1. The low rate index for CLOU calculated for these kinds of particles must be highlighted. Thus, low reactivity could limit the available oxygen by kinetic restrictions.

With regard to oxygen transport capacity during reduction with $\mathrm{H}_{2}$, see $R_{O C}^{g}$ values, similar values were found for the three materials. The reduction rate in $\mathrm{H}_{2}$ was similar for both Mn77Fe[L4] and Mn77Fe[M4]. But this value was significantly decreased for Mn77Fe[S4] manufactured with the lowest particle size of the precursor material. Finally, reactivity for oxygen uncoupling in $\mathrm{N}_{2}$ and oxidation in air (both for CLOU and CLC) also decreased as the particle size of the raw materials decreased.

The decrease in particle size of the raw materials might be thought to be able to facilitate the migration of $\mathrm{Mn}$ and $\mathrm{Fe}$ atoms to form the mixed oxide. However, it was demonstrated that bixbyite was always formed. In addition, the Mn77Fe[S4] material was prepared with a mixture of $\mathrm{Mn}$ and $\mathrm{Fe}$ oxides that had been calcined at $1050{ }^{\circ} \mathrm{C}$ for $4 \mathrm{~h}$. Thus, the Mn77Fe[S4] particles were prepared starting from the combined Mn-Fe oxide instead of individual mixed oxides. In this case, reactivity, oxygen transport capacity, porosity and mechanical strength were considerably reduced when compared to the other materials. 
From the above considerations, decreasing the particle size of raw materials, in addition to the use of a Mn-Fe mixed oxide as raw material, was not recommended since weaker and/or less reactive particles were obtained. Therefore, materials prepared using $\mathrm{Mn}$ and $\mathrm{Fe}$ oxides as raw materials with a mean particle size of $5 \mu \mathrm{m}$ were used in subsequent studies. In order to evaluate the effect of calcining conditions on the particles characteristics, an additional, more severe calcining step was performed at $1100{ }^{\circ} \mathrm{C}$ for $2 \mathrm{~h}$. The oxygen uncoupling capacity was slightly lower with respect to Mn77Fe[L4], but the decomposition rate of the bixbyite was severely decreased. Furthermore, an increase in porosity was observed which could be related to the slight decrease in mechanical strength.

Mixing active metal oxides with an inert material acting as support is a conventional option for improving the physical and chemical properties of oxygen carriers [1]. In this work, the use of kaolin $\left(\mathrm{Al}_{2} \mathrm{Si}_{2} \mathrm{O}_{5} \cdot(\mathrm{OH})_{4}\right)$ as binder material was examined. Kaolin phase undergoes structural transformations upon calcination and it is well known for its mechanical properties and resistance to thermal shock. For example, the strength of $\mathrm{Cu}$ - and $\mathrm{Fe}$-based oxygen carriers was improved by adding kaolin $[29,30]$. Both the mechanical strength and reactivity with $\mathrm{H}_{2}$ of the Mn-Fe material with 20 wt.\% kaolin (Mn77FeK[L4]) was higher than for the reference material (Mn77Fe[L4]); however, its oxygen transport capacity both with $\mathrm{H}_{2}$ and $\mathrm{N}_{2}$ was accordingly decreased.

Raw manganese oxide can be found in several oxidation states. The effect of the oxidation state of manganese powder was evaluated by preparing particles with the same Mn:Fe ratio, but using $\mathrm{MnO}_{2}$ as raw material instead of $\mathrm{Mn}_{3} \mathrm{O}_{4}$. In this case, a slight decrease in the oxygen uncoupling capacity, $R_{O C}^{o u}$, was observed for the $\mathrm{Mn} 77 \mathrm{Fe}\left[\mathrm{L} 4 \mathrm{Mn}^{(\mathrm{IV})}\right]$ material, which may have been due to incomplete oxidation to bixbyite phase; see Table 1. Its reactivity, 
both for oxygen uncoupling and reduction with $\mathrm{H}_{2}$, was also somewhat lower. Nevertheless, the mechanical strength of these particles had the lowest value of all the materials prepared.

The Mn:Fe ratio also influences mechanical strength. Thus, the material with the lowest Mn content (Mn60Fe[L4]) possessed the highest mechanical strength and reactivity with $\mathrm{H}_{2}$. Although oxygen transport capacity for oxygen uncoupling, $R_{O C}^{o u}$, was maintained, oxygen uncoupling reactivity was significantly reduced. This behaviour agrees with results obtained in previous works $[13,14]$.

From these initial tests, material Mn77Fe[L4] was chosen as benchmarking particles for the following screening based on its high crushing strength and reactivity. Thus, the Mn77FeC[L4] material showed higher porosity and reaction rate with $\mathrm{H}_{2}$ than the benchmarking material. This was due to the porosity generated when the graphite added to the solids mixture in the preparation stage was burnt during calcination. However, weaker particles were obtained. A similar behaviour was observed even when the calcining time was increased up to 12 and $18 \mathrm{~h}$ at $950^{\circ} \mathrm{C}$ for $\mathrm{Mn77FeC[L12]} \mathrm{and} \mathrm{Mn77FeC[L18],}$ respectively. Thus, only a marginal improvement was achieved by increasing the calcining time.

From the comprehensive analysis on the mechanical strength, oxygen transport capacity and reactivity, three oxygen carriers could be considered for further studies, namely Mn77Fe[L4], Mn77FeK[L4] and Mn60Fe[L4]. In this work, a detailed study on the reactivity of reduction by fuel gases and oxygen uncoupling, as well as oxidation of reduced particles, was carried out with Mn77Fe[L4]. The Mn77Fe[L4] material was selected because of its easier preparation method, its need for a relatively low calcination 
temperature and its relatively high oxygen transport capacity, and owing to the reactivity it demonstrated for oxygen uncoupling. It should be recalled that the aim of this work was the development and assessment of a Mn-Fe based oxygen carrier with oxygen capacity for coal combustion both via in-situ gasification and oxygen uncoupling pathways. Further study on reactivity and performance in a fluidized-bed reactor is presented below.

\subsection{Comprehensive evaluation of the Mn77Fe[L4] material}

\subsubsection{Analysis of oxygen uncoupling capability}

As shown by the phase diagrams in Figure 1(b), $\left(\mathrm{Mn}_{0.77} \mathrm{Fe}_{0.23}\right)_{3} \mathrm{O}_{4}$ spinel could be formed when the oxygen partial pressure was low enough, or when the temperature was high enough. But its oxygen uncoupling capability was lost for consecutive redox cycles when oxidation was carried out at $950{ }^{\circ} \mathrm{C}$ in air because bixbyite phase could not be formed at such conditions; see Section 3.1. Consequently, analysis of the operating conditions for the oxidation stage was required in order to take advantage of the gaseous oxygen release from bixbyite.

The oxygen uncoupling capability of the Mn77Fe[L4] particles was analysed as a function of the oxidizing conditions, i.e. reacting temperature and oxygen partial pressure. Redox cycles were performed in a TGA by alternating highly-pure $\mathrm{N}_{2}$ for the oxygen uncoupling stage and air or diluted air $\left(5 \mathrm{vol} . \% \mathrm{O}_{2}\right)$ for the oxidation stage. The oxidation temperature was varied in the $800-920{ }^{\circ} \mathrm{C}$ interval, but temperature in $\mathrm{N}_{2}$ was $900{ }^{\circ} \mathrm{C}$ in all cases in order to ensure full reduction to spinel $\left(\mathrm{Mn}_{0.77} \mathrm{Fe}_{0.23}\right)_{3} \mathrm{O}_{4}$.

For oxygen uncoupling, the reaction rate was unchanged with the redox cycles. Figure 3(a) shows the conversion vs time curves after 3 cycles for the oxidation period in air at different temperatures. Conversion was calculated for oxidation of spinel to bixbyite, i.e. 
$X_{o}^{o u}$. Oxidation barely took place at $920^{\circ} \mathrm{C}$, and when oxidized at $900{ }^{\circ} \mathrm{C}$, the reaction showed an induction period lasting around 20 s. A lower temperature in the oxidizing period led to a higher reaction rate up to $850{ }^{\circ} \mathrm{C}$. When the oxidation took place at 820 and $800^{\circ} \mathrm{C}$, a lower reaction rate was observed. This behaviour can be explained as the result of a trade-off between kinetic control and thermodynamic limitation. Thus, when the temperature was increased from $800^{\circ} \mathrm{C}$, the oxidation rate increased because of the increase in the kinetic rate constant. However, when the temperature was higher than $850{ }^{\circ} \mathrm{C}$, the reaction rate decreased because the oxygen concentration was close to the thermodynamic equilibrium. This behaviour was also observed for the oxygen uncoupling rate with $\mathrm{Cu}-$ based oxygen carriers, although in this case the reaction rate decreased for temperatures higher than $900-950{ }^{\circ} \mathrm{C}$ [31]. Therefore, the adequate oxidizing temperature for regeneration seemed to be in the $820-870{ }^{\circ} \mathrm{C}$ interval. Furthermore, it was found that when bixbyite was regenerated, the reduction rate in $\mathrm{N}_{2}$ was unaffected by the oxidizing conditions. During consecutive redox cycles, a stable oxygen transport capacity of around $R_{O C}^{o u}=3$ wt. $\%$ was obtained for the oxygen uncoupling reaction, which was slightly lower than the theoretical value of 3.4 wt. $\%$.

The regeneration capability of spinel to oxidize to bixbyite in diluted air $\left(5\right.$ vol. $\left.\% \mathrm{O}_{2}\right)$ was also analysed; see Figure 3(b). Under such conditions, re-oxidation from spinel to bixbyite did not take place at $885^{\circ} \mathrm{C}$, and it was slow to occur at $850{ }^{\circ} \mathrm{C}$, characterized by a long induction period lasting in the range between 150 and $200 \mathrm{~s}$. The decrease in temperature led to an improvement in the re-oxidation rate. Therefore, the adequate oxidizing temperature using $5 \mathrm{vol} . \% \mathrm{O}_{2}$ was $800-820{ }^{\circ} \mathrm{C}$. It is worth noting that an induction period was observed in all cases, but it was reduced with the temperature decrease. Also, oxidation 
was relatively fast up to $X_{o}^{o u}=0.4$ approx., after which the oxidation rate was significantly decreased. These results agree with the induction period observed by Lambert et al. [16] during oxidation of spinel to bixbyite for $\left(\mathrm{Mn}_{\mathrm{x}} \mathrm{Fe}_{1-\mathrm{x}}\right)_{2} \mathrm{O}_{3}$ materials with $\mathrm{x} \geq 0.5$.

The effect of the temperature on the oxygen uncoupling rate was also analysed in the 850$920{ }^{\circ} \mathrm{C}$ range; see Figure 3(c). In these tests, oxidation was carried out at $850{ }^{\circ} \mathrm{C}$ in air to ensure quick and complete regeneration to bixbyite. The higher the temperature, the faster the conversion rate observed during the oxygen uncoupling step. Therefore, a high temperature in the fuel reactor would be desirable.

The oxygen uncoupling capability of this material was subsequently tested in the batch fluidized-bed reactor. Several cycles alternating $\mathrm{N}_{2}$ and air or diluted air were conducted at different temperatures. Figure 4(a) shows the behaviour of the particles subjected to $\mathrm{N}_{2}$-Air cycles at temperatures between 800 and $900{ }^{\circ} \mathrm{C}$. During the decompositions, the rise in the temperature led to improved oxygen uncoupling behaviour. The material showed reproducibility when 3 cycles were conducted, regardless of temperature. In addition, agglomeration was not observed in any case, regardless of the reacting temperature or degree of reduction.

The evolution in the oxygen carrier conversion, $X_{o}^{o u}$, during both the oxygen uncoupling and the re-oxidation steps is also shown. The variation in the oxygen uncoupling conversion, $X_{o}^{o u}$, was $7 \%$ at $800{ }^{\circ} \mathrm{C}$; however, the conversion variation increased to $20 \%$ when the temperature was varied to $850{ }^{\circ} \mathrm{C}$, and it was increased by 4 when the temperature was raised from 800 to $900{ }^{\circ} \mathrm{C}$. Note that in the fluidized-bed reactor, the solid to gas ratio was higher than in the TGA, and conditions in the reactor approached those of equilibrium. Thus, the reaction rate could be increased by temperature, as was observed in TGA tests. 
But this increase was limited by oxygen concentration at the thermodynamic equilibrium. It is worthy of note that the concentration of oxygen in exiting gases increased with temperature, which mainly affected the increase in the oxygen carrier conversion.

With regard to oxidation in air, complete regeneration of the particles was observed at 800 ${ }^{\circ} \mathrm{C}$, which may have been due to the low conversion achieved during the oxygen uncoupling stage. However, full re-oxidation was not observed at higher temperatures. The fraction of oxygen recovered with the increase in temperature was $90 \%$ at $850{ }^{\circ} \mathrm{C}$ and $75 \%$ at $900{ }^{\circ} \mathrm{C}$. This result is in agreement with what was observed in the thermogravimetric tests, i.e. the oxidation rate in air decreased when temperature was increased to above 850 ${ }^{\circ} \mathrm{C}$; see Figure 3. Thus, regeneration was incomplete at $900{ }^{\circ} \mathrm{C}$, even considering that the reaction period was longer for this temperature.

In addition, several cycles alternating $\mathrm{N}_{2}$ and diluted air (5 or 10 vol.\% $\mathrm{O}_{2}$ ) were performed at $870{ }^{\circ} \mathrm{C}$ in order to evaluate the regeneration capability of $\mathrm{Mn} 77 \mathrm{Fe}[\mathrm{L} 4]$ at lower oxygen concentration values; see Figure 4(b). The first two redox cycles were performed in the fluidized-bed facility using 5 vol.\% $\mathrm{O}_{2}$ in the oxidizing step. A constant oxygen concentration of $1.3 \mathrm{vol} . \%$ was recorded during decomposition in $\mathrm{N}_{2}$. The first period in $\mathrm{N}_{2}$ lasted $15 \mathrm{~min}$, and a variation was achieved in the oxygen uncoupling conversion of $\Delta X_{o}^{\text {ou }}$ $=16.4 \%$. Following this, partial oxidation was reached after half hour in 5 vol. $\% \mathrm{O}_{2}$. The material was further reduced during the second cycle in $\mathrm{N}_{2}$, showing a trend similar to the reduction observed in the first cycle. The oxidizing time was then increased for the second cycle, but again complete re-oxidation was not achieved. Finally, oxidation was performed by using 10 vol.\% $\mathrm{O}_{2}$ in order to observe the influence of oxygen partial pressure on solids conversion. As a result, the particles were full regenerated to bixbyite. Therefore, the 
increase in the $\mathrm{O}_{2}$ partial pressure allowed a faster regeneration to bixbyite phase to be achieved.

\subsubsection{Reactivity with gaseous fuels: $\mathrm{H}_{2}, \mathrm{CO}$ and $\mathrm{CH}_{4}$}

Reduction by fuel gases could be relevant in the fuel conversion pathway [22], with special interest given to the reduction of spinel to mangano-wüstite, see Reaction R3, which is not driven by the oxygen uncoupling mechanism. Redox cycles were carried out at $950{ }^{\circ} \mathrm{C}$ with Mn77Fe[L4] particles both in the TGA and in the batch fluidized bed. In these tests, the spinel was reduced by $\mathrm{H}_{2}, \mathrm{CO}$ or $\mathrm{CH}_{4}$, while oxidation of mangano-wüstite was performed in air.

Initially, the oxygen carrier particles were subjected to 100 redox cycles in the TGA to check the stability of the material regarding oxygen transport capacity and reactivity. Reducing and oxidizing periods lasted 300 and 90 s, respectively. This time was long enough to achieve sequentially complete reduction and oxidation between the spinel and mangano-wüstite phases. Figure 5(a) shows the evolution in the conversion by reaction with fuel gas, $X_{r}^{g}$, obtained in the TGA with Mn77Fe[L4] particles. The reactivity of the particles with $\mathrm{H}_{2}$ showed an increase throughout the cycles, but oxygen transport capacity remained constant with the cycles to $R_{O C}^{g}=6.5 \mathrm{wt} . \%$. The reactivity increase observed during the last 25 cycles was of lower relevance. In addition, Figure 5(b) shows that oxidation reactivity was maintained with the redox cycles.

The subsequent analysis on reactivity was conducted with cycled particles for the spinel/mangano-wüstite redox pair. Reduction with different gaseous fuels $\left(\mathrm{H}_{2}, \mathrm{CO}\right.$ and $\mathrm{CH}_{4}$ ) and oxidation with 10 vol. $\% \mathrm{O}_{2}$ was carried out in the TGA at $950{ }^{\circ} \mathrm{C}$, and the normalized Rate index of Mn77Fe[L4] was calculated; see Figure 6. The reactivity of 
Mn77Fe[L4] with $\mathrm{H}_{2}$ was the highest, followed by that with $\mathrm{CO}$ and with $\mathrm{CH}_{4}$, respectively. The oxidation rate was similar whatever the fuel used in the reduction period. In order to ascertain the potential of this oxygen carrier in CLC, a comparison with other similar materials was performed. For this purpose, the Figure 6 also shows a comparison of Rate index values and oxygen transport capacities between these particles and other lowcost Fe-based materials that had been tested previously, i.e. ilmenite, Fe-ESF, Fe-ore, and a highly reactive Fe-based synthetic oxygen carrier [32]. The oxygen transport capacity of the $\mathrm{Mn} 77 \mathrm{Fe}[\mathrm{L} 4]$, here $R_{O C}^{g}$, was the highest among these oxygen carriers. With regard to reactivity with $\mathrm{H}_{2}, \mathrm{Mn} 77 \mathrm{Fe}[\mathrm{L} 4]$ performed significantly better compared to both ilmenite and Fe-ESF. Furthermore, these particles showed similar reactivity to that of the Fe-ore particles. With $\mathrm{CO}$, this $\mathrm{Mn}-\mathrm{Fe}$-based oxygen carrier showed similar reactivity to that observed for both Fe-ore and Fe-ESF and it was still better than that of the ilmenite. However, the reactivity of $\mathrm{Mn} 77 \mathrm{Fe}[\mathrm{L} 4]$ with $\mathrm{CH}_{4}$ was the lowest of all materials tested. With respect to the oxidizing step, these particles were very reactive, showing a rate index value with $\mathrm{O}_{2}$ close to that obtained with the ilmenite, which showed the highest reactivity. The conversion of $\mathrm{H}_{2}, \mathrm{CO}$ and $\mathrm{CH}_{4}$ was also evaluated through tests carried out in the batch fluidized-bed reactor at $950{ }^{\circ} \mathrm{C}$. Figure 7 shows the evolution of gaseous compounds and variation in solids conversion, $\Delta X_{o}^{g}$, over time. $\mathrm{Mn} 77 \mathrm{Fe}[\mathrm{L} 4]$ had high reactivity in presence of $\mathrm{H}_{2}$, reaching full conversion of $\mathrm{H}_{2}$ during the first two minutes of reduction; then a small amount of $\mathrm{H}_{2}$ was detected when $\Delta X_{o}^{g}>40 \%$. With CO combustion, the material was able to achieve a gas conversion of $96 \%$, while $\mathrm{CH}_{4}$ conversion ranged from 50 to $60 \%$ during the first 3 minutes. Thus, $\mathrm{CH}_{4}$ showed the lowest reactivity of all gases used, which was already observed in TGA tests. 
The maximum degree of reduction for the particles was achieved in the reduction with $\mathrm{H}_{2}$, where the variation in the conversion was $\Delta X_{o}^{g}=60 \%$. The oxygen carrier particles reached full regeneration after the oxidizing step in all cases. After the reduction step with $\mathrm{CH}_{4}$, both $\mathrm{CO}_{2}$ and $\mathrm{CO}$ were observed at the beginning of the oxidizing period because carbon was formed by the thermal decomposition of methane. No $\mathrm{O}_{2}$ was detected during the purge period after each oxidation, suggesting that bixbyite phase was not formed, and that the oxidation took place with spinel phase.

XRD analysis of samples extracted from the fluidized bed after both reduction and oxidation periods was performed in order to assess the phase changes indicated by performance of the material in the redox cycles. Thus, bixbyite phase was found to be a major component in regenerated samples at temperatures below $870{ }^{\circ} \mathrm{C}$. However, only spinel phase was found in samples oxidized after reduction with fuel gases at $950{ }^{\circ} \mathrm{C}$. XRD analysis was also performed on a sample extracted from the fluidized bed reactor after a reduction period with $\mathrm{H}_{2}$. In this case, only mangano-wüstite phase was found. The assignation of crystalline phases was performed through the use of the DIFFRAC.EVA software, based on Joint Committee on Powder Diffraction Standards. Thus, bixbyite phase included $\mathrm{MnFeO}_{3}$ and $\mathrm{Mn}_{2} \mathrm{O}_{3}$ structures, while $\mathrm{Mn}_{2} \mathrm{FeO}_{4}, \mathrm{MnFe}_{2} \mathrm{O}_{4}, \mathrm{Mn}_{3} \mathrm{O}_{4}$ and $\mathrm{Fe}_{3} \mathrm{O}_{4}$ were present in the spinel phase. Finally, crystalline $\mathrm{Mn}_{\mathrm{x}} \mathrm{Fe}_{1-\mathrm{x}} \mathrm{O}$ and $\mathrm{MnO}$ were included in the mangano-wüstite phase.

In general, the results obtained in the fluidized bed agreed with the results obtained in the TGA. Moreover, good fluid-dynamic behaviour of the particles throughout the redox cycles was observed. Proper fluidization was maintained during all conditions used in these tests, 
without agglomeration or de-fluidization problems regardless of the operating conditions used, i.e. temperature, fuel gas or degree of reduction.

\section{Discussion}

From results showed in this work, some practical implications can be drawn from the use of the $\mathrm{Mn} 77 \mathrm{Fe}[\mathrm{L} 4]$ material for fuel combustion via CLC or CLOU.

Prepared Mn-Fe materials could transfer oxygen via oxygen uncoupling and gas-solid reaction with a fuel gas; but their oxygen transport capacity for oxygen uncoupling, $R_{O C}^{o u}$, was much lower than the total oxygen transport capacity, $R_{O C}^{t}$; see Table 2 . It is expected that both mechanisms will be involved in the oxygen transfer process from the oxygen carrier to the fuel [22]. In fact, the overall process for converting a fuel could be described as conventional Chemical Looping assisted by Oxygen Uncoupling (CLaOU). Therefore, both oxygen uncoupling and reduction reactions with fuel gases, which also exist in CLC with coal, must be analysed in order to provide a complete evaluation of these materials.

With regard to reduction with fuel gases, which is a characteristic process in CLC, reduction to mangano-wüstite phase, $\mathrm{Mn}_{0.77} \mathrm{Fe}_{0.23} \mathrm{O}$, could be exploited. The reactivity of the $\mathrm{Mn} 77 \mathrm{Fe}[\mathrm{L} 4]$ material was similar to that shown by other proposed materials such as ilmenite or iron ore. Fast oxidation to spinel, $\left(\mathrm{Mn}_{0.77} \mathrm{Fe}_{0.23}\right)_{3} \mathrm{O}_{4}$, is expected in the air reactor, with an oxygen transport capacity of $R_{O C}^{g}=6.5 \mathrm{wt} . \%$. Considering the promising results obtained with Fe-ore or Fe-ESF oxygen carriers burning syngas [33] or coal $[34,35]$, the Mn77Fe[L4] material can be proposed for use in CLC with these fuels. In addition, the high oxygen transport capacity of $\mathrm{Mn} 77 \mathrm{Fe}[\mathrm{L} 4]$ is of relevance, which means that a lower 
solids circulation flow would be required, which benefits the $\mathrm{CO}_{2}$ capture that is achievable in CLC of coal [36].

In addition, the oxygen uncoupling capability of this material could be exploited when bixbyite phase, $\left(\mathrm{Mn}_{0.77} \mathrm{Fe}_{0.23}\right)_{2} \mathrm{O}_{3}$, was formed. In this case, an improved performance of coal combustion can be expected compared to the $\mathrm{CO}_{2}$ capture and combustion efficiency achieved with non-CLOU materials $[5,6]$. For this to occur, the spinel should be able to become oxidized to bixbyite at any oxygen concentration existing inside the air reactor to take advantage of the oxygen uncoupling property of the Mn77Fe[L4] material. The oxygen concentration is high ( $21 \mathrm{vol} . \%)$ near the air inlet and quick oxidation to bixbyite will be expected at temperatures in the $800-900{ }^{\circ} \mathrm{C}$ interval. However, the oxygen concentration decreases as the oxygen reacts with the oxygen carrier. Thus, considering an air excess similar to that used in conventional combustion, the oxygen concentration will decrease to around 4-6 vol.\% at the air reactor exit. Under these conditions, the oxidation rate will decrease, but it may be of relevance if the temperature is in the $800-850{ }^{\circ} \mathrm{C}$ interval. Thus, an average temperature in the air reactor of around $850{ }^{\circ} \mathrm{C}$ would guarantee proper oxidation to bixbyite phase.

With regard to the oxygen uncoupling mechanism, it was determined that a high temperature in the fuel reactor would be desirable. Consequently, the reaction rate of oxygen generation by oxygen uncoupling at $920{ }^{\circ} \mathrm{C}$ was calculated to be $1.9 \cdot 10^{-4} \mathrm{~kg} / \mathrm{s}$ per $\mathrm{kg}$ of oxygen carrier. This value is half of the reaction rate obtained for $\mathrm{Cu}$-based materials [31], and in the same order of magnitude as that found for Mn-based perovskites at $920^{\circ} \mathrm{C}$ [37]. 
In conclusion, in the CLOU process with $\mathrm{Mn}-\mathrm{Fe}$ materials, both the oxygen generation from bixbyite decomposition to spinel phase and bixbyite regeneration must take place in the fuel reactor and air reactor, respectively. For the Mn77Fe[L4] material, the maximum temperature inside the air reactor should be $850{ }^{\circ} \mathrm{C}$, while the temperature inside the fuel reactor must be as high as possible. Therefore, a thermal gradient between the fuel and air reactor has to be set in order to take advantage of the oxygen uncoupling capacity of this material. The temperatures in the reactors are closely linked by an overall enthalpy balance to the CLC unit. The lower temperature in the air reactor would be achieved by extracting heat from this reactor. The use of a higher temperature in the fuel reactor could be viable as long as the overall process taking place in the fuel reactor is exothermic when bixbyite is reduced to spinel [10]. Preliminary calculations showed that the thermal gradient would rise to $70{ }^{\circ} \mathrm{C}$, which means that suitable temperatures would be $920^{\circ} \mathrm{C}$ in the fuel reactor and $850{ }^{\circ} \mathrm{C}$ in the air reactor. However, the overall process in the fuel reactor becomes less exothermic when bixbyite is reduced to mangano-wüstite. This fact would limit the maximum temperature in the fuel reactor. In order to have a higher temperature in the fuel reactor, the temperature in the air reactor must be increased. Thus, the air excess should be increased to facilitate bixbyite regeneration. This option implies increased power consumption for air impulsion; but it could turn out to be an interesting option if the oxygen uncoupling capability of the Mn77Fe[L4] material is preserved. In this way, the expected combustion efficiency would be higher compared to operation without the oxygen uncoupling capability, i.e. in the $i \mathrm{G}-\mathrm{CLC}$ mode for solid fuels.

\section{Conclusions}


A screening of $\left(\mathrm{Mn}_{0.77} \mathrm{Fe}_{0.33}\right)_{2} \mathrm{O}_{3}$ particulate material obtained by mechanical mixing followed by pelletizing under pressure was developed for the purpose of producing strong and high reactive particles for use in CLC and CLOU. Bixbyite phase was formed in all cases, showing oxygen transfer via both gas-solid reaction with fuel gases and oxygen uncoupling. Mn77Fe[L4], which was prepared from $\mathrm{Mn}_{3} \mathrm{O}_{4}$ and $\mathrm{Fe}_{2} \mathrm{O}_{3}$ powders $(5 \mu \mathrm{m})$ and calcined at $950{ }^{\circ} \mathrm{C}$ for $4 \mathrm{~h}$, showed enough reactivity and mechanical strength to be used as an oxygen carrier for both CLC and CLOU. The use of finer powders, Mn-Fe combined oxide or $\mathrm{MnO}_{2}$ as raw materials, the increase of calcining temperature from 950 to $1100{ }^{\circ} \mathrm{C}$, the addition of graphite to the $\mathrm{Mn}_{3} \mathrm{O}_{4}-\mathrm{Fe}_{2} \mathrm{O}_{3}$ mixture, and the modification of the composition to $\left(\mathrm{Mn}_{0.6} \mathrm{Fe}_{0.4}\right)_{2} \mathrm{O}_{3}$ was unable to improve either the reactivity or the mechanical strength of the benchmarking material. Mechanical strength and reactivity were improved by adding kaolin powder to the $\mathrm{Mn}_{3} \mathrm{O}_{4}-\mathrm{Fe}_{2} \mathrm{O}_{3}$ mixture, but the oxygen transport capacity was correspondingly decreased as kaolin acts as a diluting material.

The Mn77Fe[L4] material was further analysed by tests in a TGA and a fluidized-bed reactor. This material was able to generate oxygen gas phase by the reduction of $\left(\mathrm{Mn}_{0.77} \mathrm{Fe}_{0.33}\right)_{2} \mathrm{O}_{3}$ bixbyite to $\left(\mathrm{Mn}_{0.77} \mathrm{Fe}_{0.33}\right)_{3} \mathrm{O}_{4}$ spinel. The oxygen uncoupling reaction rate increased with temperature, and became fast enough to be exploited in a CLC unit at 900 ${ }^{\circ} \mathrm{C}$. But oxidation conditions must be carefully controlled in order to take advantage of the oxygen uncoupling mechanism. Thus, a temperature lower than $900{ }^{\circ} \mathrm{C}$ in air and $850{ }^{\circ} \mathrm{C}$ in 5 vol. $\% \mathrm{O}_{2}$ is advisable to allow bixbyite formation. Therefore, a thermal gradient between the fuel and air reactor of around $70{ }^{\circ} \mathrm{C}$ would need to be used in CLOU, with the higher temperature inside the fuel reactor. In addition, complete reduction to mangano-wüstite, $\left(\mathrm{Mn}_{0.77} \mathrm{Fe}_{0.33}\right) \mathrm{O}$, was achieved by reaction with a gaseous fuel, i.e. $\mathrm{H}_{2}, \mathrm{CO}$ or $\mathrm{CH}_{4}$. This 
material could be considered a candidate for use as an oxygen carrier in CLC with syngas or coal. Moreover, good fluid-dynamic behaviour of the particles was observed throughout the redox cycles in a fluidized bed without agglomeration problems, regardless of the operating conditions used.

\section{Acknowledgements}

This work was partially supported by the Spanish Ministry for Economy and Competitiveness via the ENE2013-45454-R project, by the European Regional Development Fund (ERDF), and by the Spanish National Research Council (CSIC) via the 2014-80E101 project. R. Pérez-Vega is grateful to MICINN for the FPI Fellowship. 


\section{Nomenclature}

$F_{i} \quad$ total molar flow gas at inlet $(i=i n)$ or outlet $(i=o u t)$ in the batch fluidized-bed reactor $(\mathrm{mol} / \mathrm{s})$

$M_{O} \quad$ atomic mass of oxygen $\left(16 \cdot 10^{-3} \mathrm{~kg} / \mathrm{mol}\right)$

$m \quad$ instantaneous mass of the oxygen carrier $(\mathrm{kg})$

$m_{i} \quad$ mass of oxidized $(i=o)$ or reduced $(i=r)$ sample of the oxygen carrier $(\mathrm{kg})$.

$m_{O C} \quad$ mass of the oxygen carrier within the batch fluidized-bed reactor $(\mathrm{kg})$

$m_{O C, F R} \quad$ solids inventory in the fuel reactor $(\mathrm{kg})$

$P_{\text {ref }} \quad$ reference partial pressure of reacting gas (atm)

$P_{T G A} \quad$ partial pressure of the gaseous fuel used in TGA (atm)

$R_{O C}^{o u} \quad$ oxygen transport capacity by the oxygen uncoupling reaction between bixbyite and spinel (kg oxygen per kg of oxygen carrier)

$R_{O C}^{g} \quad$ oxygen transport capacity by the solid-fuel gas reaction between spinel and mangano-wüstite (kg oxygen per kg of oxygen carrier)

$R_{O C}^{t} \quad$ total oxygen transport capacity of the oxygen carrier between bixbyite and mangano-wüstite (kg oxygen per kg of oxygen carrier)

$r_{O}(t)$ atomic oxygen transfer rate as function of time from the oxygen carrier to the fuel $\left(\mathrm{mol} \mathrm{O} / \mathrm{s}^{-1}\right)$

$t \quad$ time (s)

$X_{j}^{o u} \quad$ solids conversion by the oxygen uncoupling reaction between bixbyite and spinel $(-)$

$X_{j}^{g} \quad$ solids conversion by the solid-fuel gas reaction between spinel and manganowüstite (-)

$X_{j}^{t} \quad$ total solids conversion of the oxygen carrier between bixbyite and manganowüstite (-)

Greek symbols

$\gamma_{\mathrm{i}} \quad$ molar fraction of the gas $\mathrm{i}\left(\mathrm{i}=\mathrm{CO}, \mathrm{CO}_{2}, \mathrm{H}_{2} \mathrm{O}\right.$ or $\left.\mathrm{O}_{2}\right)(-)$

$\omega \quad$ normalized mass-loss variation (-)

Acronyms

CCS $\quad \mathrm{CO}_{2}$ Capture and Storage

CLaOU Chemical Looping assisted by Oxygen Uncoupling 
CLC Chemical Looping Combustion

CLOU Chemical Looping with Oxygen Uncoupling

FTIR Fourier Transform Infrared

I.D. Internal Diameter

$i$ G-CLC in-situ Gasification Chemical Looping Combustion

NDIR Non-Dispersive Infrared

TGA Thermogravimetric Analyser

XRD X-Ray Diffraction 


\section{References}

[1] J. Adanez, A. Abad, F. García-Labiano, P. Gayán, L.F. de Diego, Progress in ChemicalLooping Combustion and Reforming technologies, Prog. Energy. Comb. Sci. 38 (2012) 215-82.

[2] A. Lyngfelt, Chemical-looping combustion of solid fuels - Status of development, App. Energy 113 (2014) 1869-73.

[3] T. Mattisson, A. Lyngfelt, H. Leion, Chemical-looping with oxygen uncoupling for combustion of solid fuels, Int. J. Greenhouse Gas Control 3 (2009) 11-9.

[4] A. Abad, I. Adánez-Rubio, P. Gayán, F. García-Labiano, L.F. de Diego, J. Adánez, Demonstration of chemical-looping with oxygen uncoupling (CLOU) process in a 1.5 $\mathrm{kW}_{\text {th }}$ continuously operating unit using a Cu-based oxygen-carrier, Int. J. Greenhouse Gas Control 6 (2012) 189-200.

[5] T. Mendiara, I. Adánez-Rubio, P. Gayán, A. Abad, L. F. de Diego, F. García-Labiano, J. Adánez, Process Comparison for Biomass Combustion: In Situ GasificationChemical Looping Combustion (iG-CLC) versus Chemical Looping with Oxygen Uncoupling (CLOU), Energy Technol. 4 (2016) 1130-6.

[6] J. Adánez, P. Gayán, I. Adánez-Rubio, A. Cuadrat, T. Mendiara, A. Abad, F. GarcíaLabiano, L. F. de Diego, Energy Procedia 37 ( 2013) 540-9.

[7] T. Mattisson, Materials for Chemical-Looping with Oxygen Uncoupling, ISRN Chemical Engineering, Volume 2013, Article ID 526375, 19 pages.

[8] Q. Imtiaz, D. Hosseini, C.R. Müller, Review of Oxygen Carriers for Chemical Looping with Oxygen Uncoupling (CLOU): Thermodynamics, Material Development, and Synthesis, Energy Technol. 1 (2013) 633-47. 
[9] P. Perrot, Ternary Alloy Systems: Phase Diagrams, Crystallographic and Thermodynamics Data. Iron Systems, Part 4; Springer, 2008, DOI: 10.1007/978-3540-78644-3_18.

[10] M. Rydén, H. Leion, T. Mattisson, A. Lyngfelt, Combined oxides as oxygen-carrier material for chemical-looping with oxygen uncoupling, Appl. Energy 113 (2014) 192432.

[11] Y. Larring, C. Braley, M. Pishahang, K.A. Andreassen, R. Bredesen, Evaluation of a Mixed Fe-Mn Oxide System for Chemical Looping Combustion, Energy Fuels 29 (2015) 3438-45.

[12] A. Shafiefarhood, A. Stewart, F. Li, Iron-containing mixed-oxide composites as oxygen carriers for Chemical Looping with Oxygen Uncoupling (CLOU), Fuel 139 (2015) 1-10.

[13] G. Azimi, H. Leion, M. Rydén, T. Mattisson, A. Lyngfelt, Investigation of Different Mn-Fe Oxides as Oxygen Carrier for Chemical-Looping with Oxygen Uncoupling (CLOU), Energy Fuels 27 (2013) 367-77.

[14] A. Shulman, E. Cleverstam, T. Mattisson, A. Lyngfelt, Manganese/Iron, Manganese/Nickel, and Manganese/Silicon Oxides Used in Chemical-Looping With Oxygen Uncoupling (CLOU) for Combustion of Methane, Energy Fuels 23 (2009) 5269-75.

[15] G. Azimi, M. Rydén, H. Leion, T. Mattisson, A. Lyngfelt, $\left(\mathrm{Mn}_{\mathrm{z}} \mathrm{Fe}_{1-\mathrm{z}}\right)_{\mathrm{y}} \mathrm{O}_{\mathrm{x}}$ Combined Oxides as Oxygen Carrier for Chemical-Looping with Oxygen Uncoupling, AIChE J. 59 (2013) 582-88. 
[16] A. Lambert, C. Delquié, I. Clémençon, E. Comte, V. Lefebvre, J. Rousseau, B. Durand, Synthesis and characterization of bimetallic Fe/Mn oxides for chemical looping combustion, Energy Procedia 1 (2009) 375-81.

[17] B. Wang, C. Gao, W. Wang, H. Zhao, C. Zheng, Sulfur evolution in chemical looping combustion of coal with $\mathrm{MnFe}_{2} \mathrm{O}_{4}$ oxygen carrier, J. Env. Sci. 26 (2014) 106270.

[18] P. Mungse, G. Saravanan, S. Rayalu, N. Labhsetwar, Mixed Oxides of Iron and Manganese as Potential Low- Cost Oxygen Carriers for Chemical Looping Combustion, Energy Technol. 3 (2015) 856-65.

[19] E. Ksepko, R.V. Siriwardane, H. Tian, T. Simonyi, M. Sciazko, Effect of $\mathrm{H}_{2} \mathrm{~S}$ on Chemical Looping Combustion of Coal-Derived Synthesis Gas over Fe-Mn Oxides Supported on Sepiolite, $\mathrm{ZrO}_{2}$, and $\mathrm{Al}_{2} \mathrm{O}_{3}$, Energy Fuels 26 (2012) 2461-72.

[20] S. Bhavsar, B. Tackett, G. Veser, Evaluation of iron- and manganese-based monoand mixed-metallic oxygen carriers for chemical looping combustion, Fuel 136 (2014) $268-79$.

[21] M. Abián, A. Abad, M.T. Izquierdo, P. Gayán, L.F. de Diego, F. García-Labiano, J. Adánez. Titanium substituted manganese-ferrite as an oxygen carrier with permanent magnetic properties for chemical looping combustion of solid fuels, Fuel 195 (2017) $38-48$.

[22] R. Pérez-Vega, A. Abad, J. Adánez, L.F. de Diego, F. García-Labiano, P. Gayán, Development of a Mn-Fe-Ti based Oxygen Carrier in Chemical Looping Combustion with coal, Proceedings of the $7^{\text {th }}$ International Conference on Clean Coal Technologies, Krakow, Poland, 2015. 
[23] M. Rydén, A. Lyngfelt, T. Mattisson, Combined manganese/iron oxides as oxygen carrier for chemical looping combustion with oxygen uncoupling (CLOU) in a circulating fluidized bed reactor system, Energy Procedia 4 (2011) 341-8.

[24] M.I. Rosales, A.M. Plata, M.E. Nicho, A. Brito, M.A. Ponce, V.M. Castaño, Effect of sintering conditions on microstructure and magnetic properties of $\mathrm{Mn}-\mathrm{Zn}$ ferrites, $\mathrm{J}$. Mater. Sci. 30 (1995) 4446-50.

[25] L.F. de Diego, A. Abad, A. Cabello, P. Gayán, F. García-Labiano, J. Adánez, Reduction and Oxidation Kinetics of a $\mathrm{CaMn}_{0.9} \mathrm{Mg}_{0.1} \mathrm{O}_{3-\delta}$ Oxygen Carrier for ChemicalLooping Combustion, Ind. Eng. Chem. Res. 53 (2014) 87-103.

[26] L.F. de Diego, P. Gayán, F. García-Labiano, J. Celaya, A. Abad, J. Adánez, Impregnated $\mathrm{CuO} / \mathrm{Al}_{2} \mathrm{O}_{3}$ Oxygen Carriers for Chemical-Looping Combustion: Avoiding Fluidized Bed Agglomeration, Energy Fuels 19 (2005) 1850-6.

[27] M. Johansson, T. Mattisson, A. Lyngfelt, Comparison of oxygen carriers for Chemical-Looping Combustion, Therm. Sci. 10 (2006) 93-107.

[28] A. Cabello, P. Gayán, F. García-Labiano, L.F. de Diego, A. Abad, J. Adánez, On the attrition evaluation of oxygen carriers in Chemical Looping Combustion, Fuel Proc. Technol. 148 (2016) 188-197.

[29] J. Adánez, P. Gayán, A. Abad, F. García-Labiano, L.F. de Diego, Suitability of Cubased Materials for the Scale-up of Chemical Looping Combustion, in: Carbon Dioxide Capture for Storage in Deep Geological Formations, Volume 4, Chapter 17. Ed. K.F. Gerdes, 2015 CPL Press and BPCNAI. 
[30] P. Cho, T. Mattisson, A. Lyngfelt, Comparison of iron-, nickel-, copper- and manganese-based oxygen carriers for chemical-looping combustion, Fuel 83 (2004) 1215-25.

[31] I. Adánez-Rubio, P. Gayán, A. Abad, F. García-Labiano, L.F. de Diego, J. Adánez, Kinetic analysis of a $\mathrm{Cu}$-based oxygen carrier: Relevance of temperature and oxygen partial pressure on reduction and oxidation reactions rates in Chemical Looping with Oxygen Uncoupling (CLOU), Chem. Eng. J. 256 (2014) 69-84.

[32] T. Mendiara, R. Pérez, A. Abad, L.F. de Diego, F. García-Labiano, P. Gayán, J. Adánez, Low-Cost Fe-Based Oxygen Carrier Materials for the $i$ G-CLC Process with Coal. 1, Ind. Eng. Chem. Res. 51 (2012) 16216-29.

[33] M.A. Pans, A. Abad, L.F. de Diego, F. García-Labiano, P. Gayán, J. Adánez, Performance of a low-cost iron ore as an oxygen carrier for Chemical Looping Combustion of gaseous fuels, Chem. Eng. Res. Des. 93 (2015) 736-46.

[34] T. Mendiara, L.F. de Diego, F. García-Labiano, P. Gayán, A. Abad, J. Adánez, On the use of a highly reactive iron ore in Chemical Looping Combustion of different coals, Fuel 126 (2014) 239-49.

[35] T. Mendiara, L.F. de Diego, F. García-Labiano, P. Gayán, A. Abad, J. Adánez, Behaviour of a bauxite waste material as oxygen carrier in a $500 \mathrm{~W}_{\text {th }}$ CLC unit with coal, Int. J. Greenhouse Gas Control 17 (2013) 170-82.

[36] J. Adánez, A. Abad, T. Mendiara, P. Gayán, L.F. de Diego, F. García-Labiano, Review and assessment of experimental results from Chemical Looping Combustion units burning solid fuels, Progress in Energy and Combustion Science, submitted for publication. 
[37] A. Abad, F. García-Labiano, P. Gayán, L.F. de Diego, J. Adánez, Redox kinetics of $\mathrm{CaMg}_{0.1} \mathrm{Ti}_{0.125} \mathrm{Mn}_{0.775} \mathrm{O}_{2.9-\delta}$ for Chemical Looping Combustion (CLC) and Chemical Looping with Oxygen Uncoupling (CLOU), Chem. Eng. J. 269 (2015) 67-81.

\section{List of Figure captions}

Figure 1. $\mathrm{Mn}-\mathrm{Fe}-\mathrm{O}$ phase diagram as a function of (a) $\mathrm{Mn} /(\mathrm{Mn}+\mathrm{Fe})$ ratio and temperature with an $\mathrm{O}_{2}$ partial pressure of 0.05 atm $(-)$ or 0.21 atm (----); and (b): $\mathrm{O}_{2}$ partial pressure and temperature for the molar ratio $\mathrm{Mn} /(\mathrm{Mn}+\mathrm{Fe})=0.8$. Solid phases calculated with FactSage ${ }^{\mathrm{TM}}$ software using FToxid database: $\beta \mathrm{Sp}$ : $\beta$ Spinel; Bix: Bixbyite; $\mathrm{Fe}(\mathrm{s})$ and $\mathrm{Fe}(\mathrm{s} 2)$ : Iron metal; Hem: Hematite; MW: Mangano-wustite; TSp: Tetragonal Spinel.

Figure 2. Normalized mass-loss variation $(\omega)$ of $\mathrm{Mn} 77 \mathrm{Fe}[\mathrm{L} 4]$ at $950{ }^{\circ} \mathrm{C}$ for the consecutive reactions $\mathrm{R} 1$ and $\mathrm{R} 2+\mathrm{R} 3$ : reduction in $5 \mathrm{vol} . \% \mathrm{H}_{2}+40 \mathrm{vol} . \% \mathrm{H}_{2} \mathrm{O}$ and oxidation in air.

Figure 3. Oxygen carrier conversion for oxygen uncoupling (reaction R1) versus time of Mn77Fe[L4] after 3 redox cycles in TGA: (a) oxidation of spinel in air; (b) oxidation of spinel in 5 vol. $\% \mathrm{O}_{2}$; (c) decomposition of bixbyite in highly-pure $\mathrm{N}_{2}$.

Figure 4. Oxygen concentration and variation in solids conversion by oxygen uncoupling (reaction R1) during the decomposition-oxidation cycles of Mn77Fe[L4] in the fluidizedbed reactor: (a) $\mathrm{N}_{2}$-Air at different temperatures ; (b) $\mathrm{N}_{2}$-dilued air at $870{ }^{\circ} \mathrm{C}$.

Figure 5. Evolution of the conversion vs time curves during reduction (reaction R3), $X_{r}^{g}$, and oxidation, $X_{o}^{g}$, reactions for $\mathrm{Mn} 77 \mathrm{Fe}[\mathrm{L} 4]$ particles during 100 redox cycles at $950{ }^{\circ} \mathrm{C}$ in TGA: (a): Reduction in 5 vol. $\% \mathrm{H}_{2}+40$ vol. $\% \mathrm{H}_{2} \mathrm{O}$; (b): Oxidation in air.

Figure 6. Normalized Rate index of Mn77Fe[L4] particles with different gases and oxygen transport capacity, $R_{O C}^{g}$, considering spinel/mangano-wustite as the redox system (see reaction $\mathrm{R} 3$ as an example for $\mathrm{H}_{2}$ ). Data for other previously tested oxygen carriers have been also included for comparison purposes [32].

Figure 7. Gas distribution and variation in the conversion of Mn77Fe[L4] oxygen carrier, $\Delta X_{o}^{g}$, for the spinel/mangano-wustite redox system (see reaction $\mathrm{R} 3$ as an example for $\mathrm{H}_{2}$ ) during the reduction at $950{ }^{\circ} \mathrm{C}$ in the fluidized bed with: (a) 50 vol. $\% \mathrm{H}_{2},+20$ vol. $\% \mathrm{H}_{2} \mathrm{O}$; (b) 50 vol. $\% \mathrm{CO}+20$ vol. $\% \mathrm{CO}_{2}$; (c) 25 vol. $\% \mathrm{CH}_{4},+10$ vol. $\% \mathrm{H}_{2} \mathrm{O}$. Subsequent oxidation in air is also included. R: reduction; P: purge; O: oxidation. 

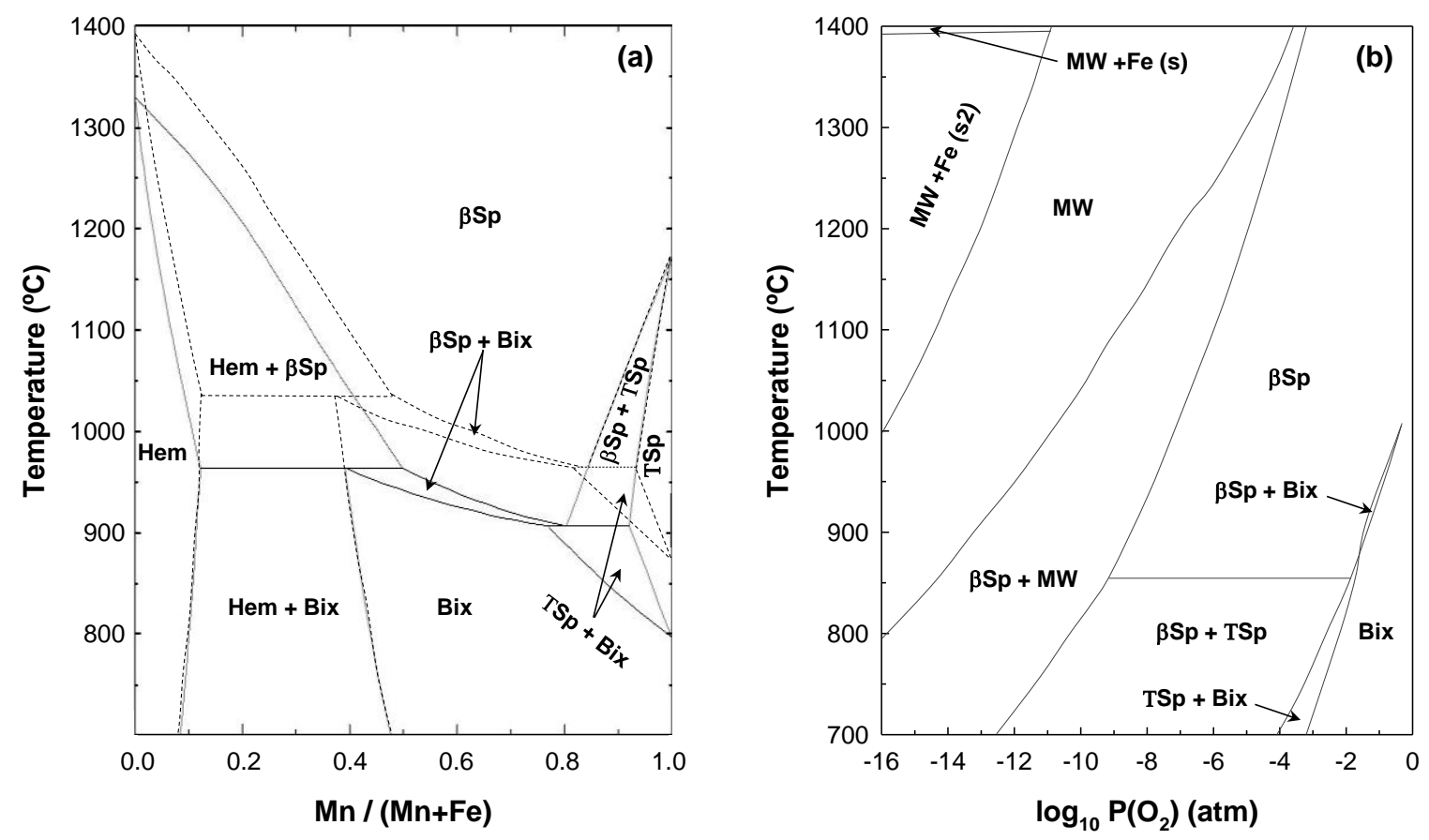

Figure 1. Mn-Fe-O phase diagram as a function of (a) $\mathrm{Mn} /(\mathrm{Mn}+\mathrm{Fe})$ ratio and temperature with an $\mathrm{O}_{2}$ partial pressure of 0.05 atm (-) or 0.21 atm (-----); and (b): $\mathrm{O}_{2}$ partial pressure and temperature for the molar ratio $\mathrm{Mn} /(\mathrm{Mn}+\mathrm{Fe})=0.8$. Solid phases calculated with FactSage $^{\mathrm{TM}}$ software using FToxid database: $\beta$ Sp: $\beta$ Spinel; Bix: Bixbyite; $\mathrm{Fe}(\mathrm{s})$ and Fe(s2): Iron metal; Hem: Hematite; MW: Mangano-wustite; TSp: Tetragonal Spinel. 


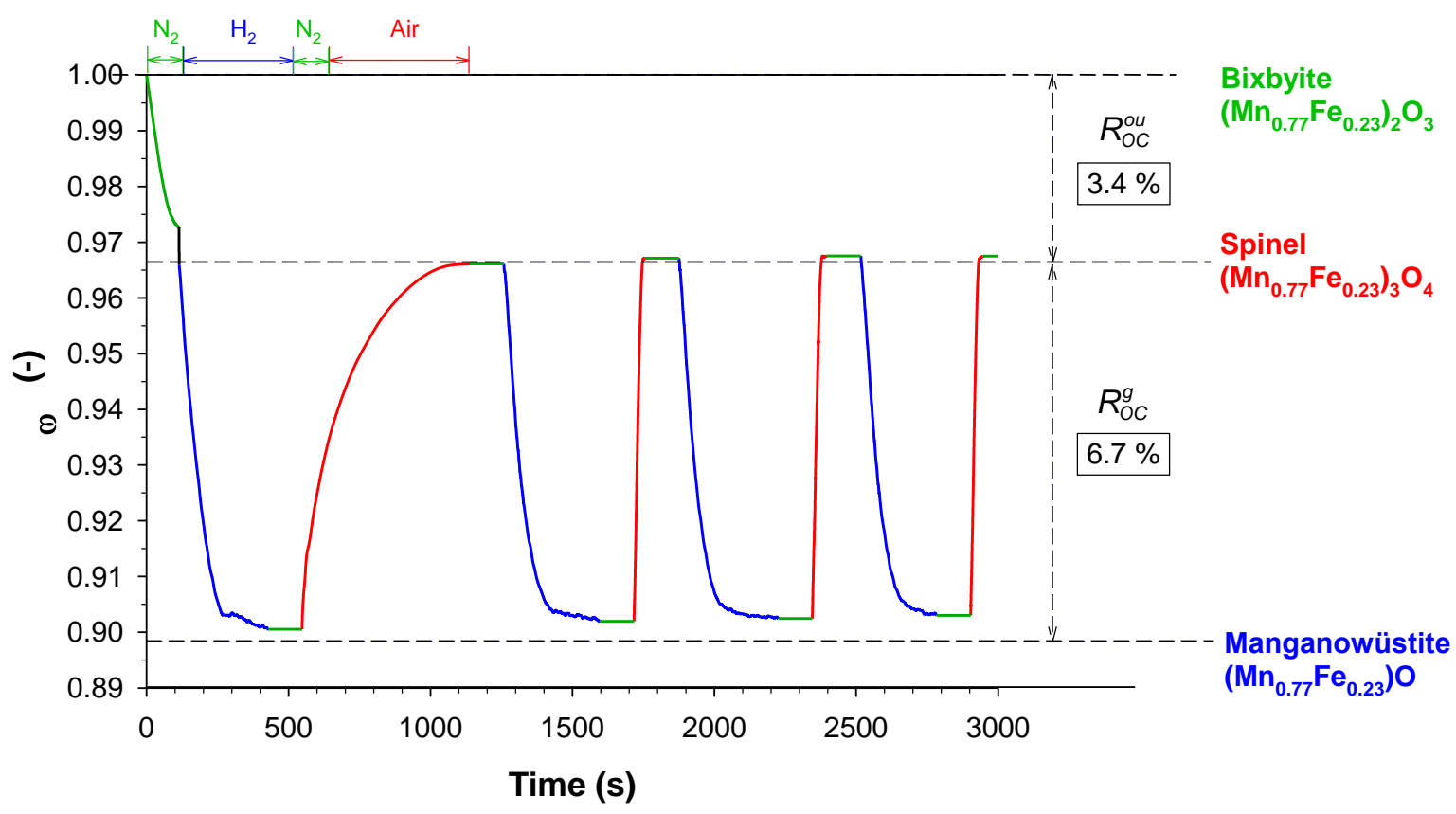

Figure 2. Normalized mass-loss variation $(\omega)$ of $\mathrm{Mn} 77 \mathrm{Fe}[\mathrm{L} 4]$ at $950{ }^{\circ} \mathrm{C}$ for the consecutive reactions $\mathrm{R} 1$ and $\mathrm{R} 2+\mathrm{R} 3$ : reduction in 5 vol. $\% \mathrm{H}_{2}+40$ vol. $\% \mathrm{H}_{2} \mathrm{O}$ and oxidation in air. 


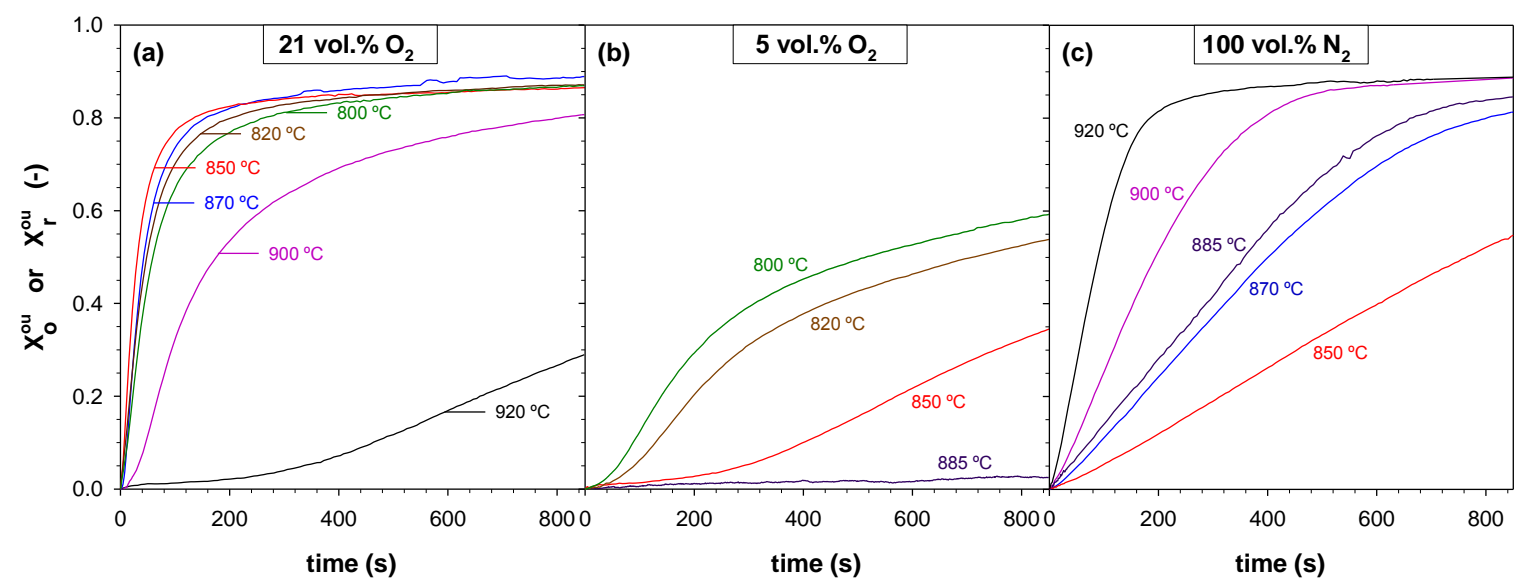

Figure 3. Oxygen carrier conversion for oxygen uncoupling (reaction R1) versus time of Mn77Fe[L4] after 3 redox cycles in TGA: (a) oxidation of spinel in air; (b) oxidation of spinel in 5 vol.\% $\mathrm{O}_{2}$; (c) decomposition of bixbyite in highly-pure $\mathrm{N}_{2}$. 


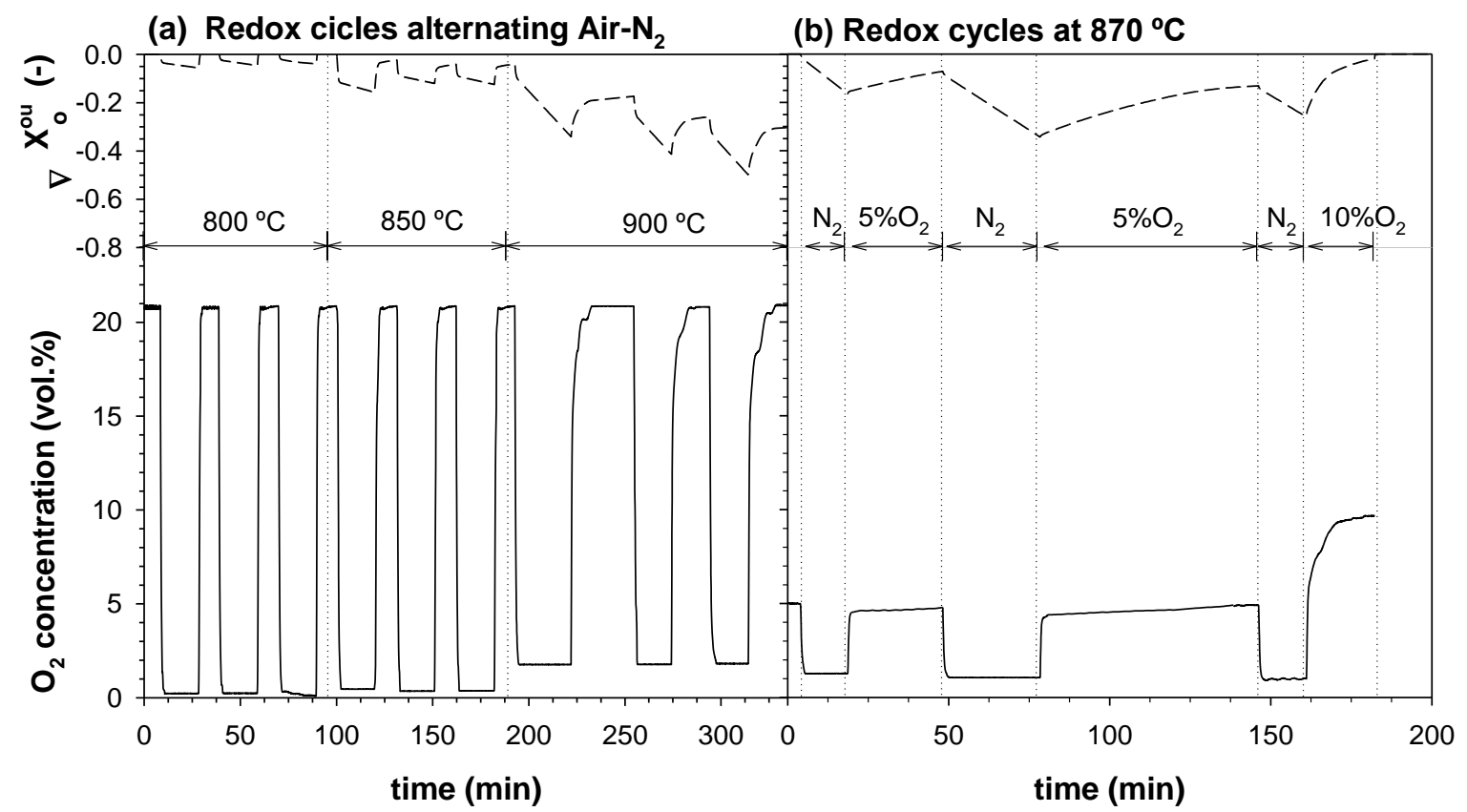

Figure 4. Oxygen concentration and variation in solids conversion by oxygen uncoupling (reaction R1) during the decomposition-oxidation cycles of Mn77Fe[L4] in the fluidizedbed reactor: (a) $\mathrm{N}_{2}$-Air at different temperatures ; (b) $\mathrm{N}_{2}$-dilued air at $870{ }^{\circ} \mathrm{C}$. 


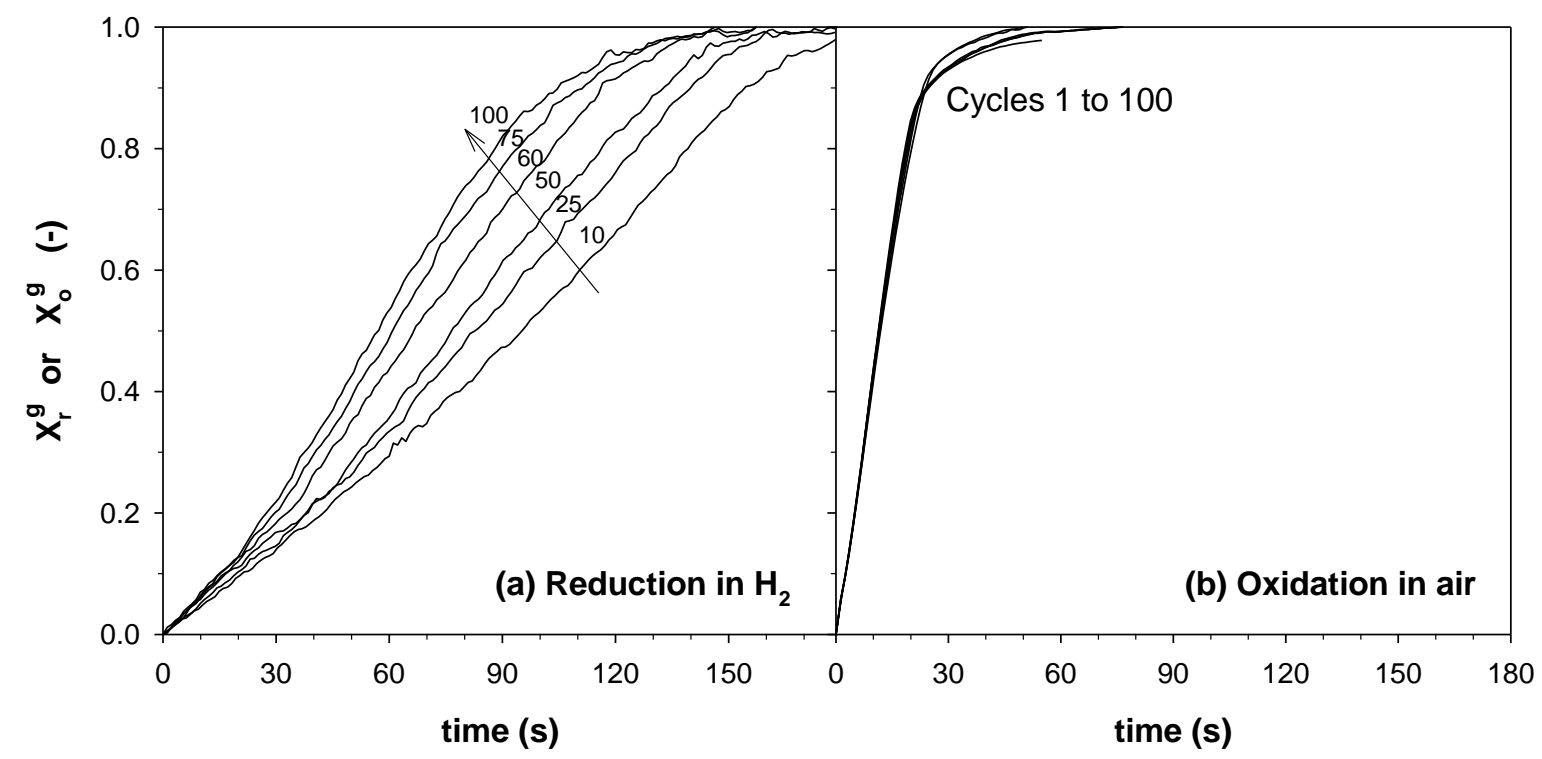

Figure 5. Evolution of the conversion vs time curves during reduction (reaction R3), $X_{r}^{g}$, and oxidation, $X_{o}^{g}$, reactions for $\mathrm{Mn} 77 \mathrm{Fe}[\mathrm{L} 4]$ particles during 100 redox cycles at $950{ }^{\circ} \mathrm{C}$ in TGA: (a): Reduction in 5 vol.\% $\mathrm{H}_{2}+40$ vol. $\% \mathrm{H}_{2} \mathrm{O}$; (b): Oxidation in air. 


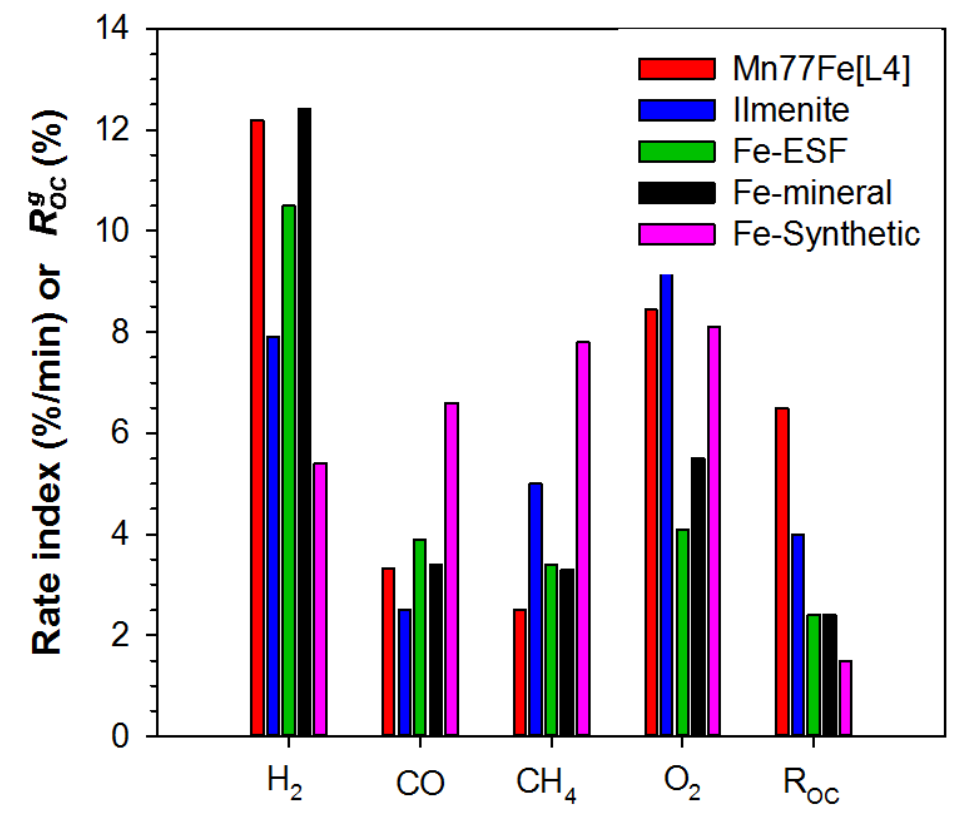

Figure 6. Normalized Rate index of Mn77Fe[L4] particles with different gases and oxygen transport capacity, $R_{O C}^{g}$, considering spinel/mangano-wustite as the redox system (see reaction $\mathrm{R} 3$ as an example for $\mathrm{H}_{2}$ ). Data for other previously tested oxygen carriers have been also included for comparison purposes [32]. 


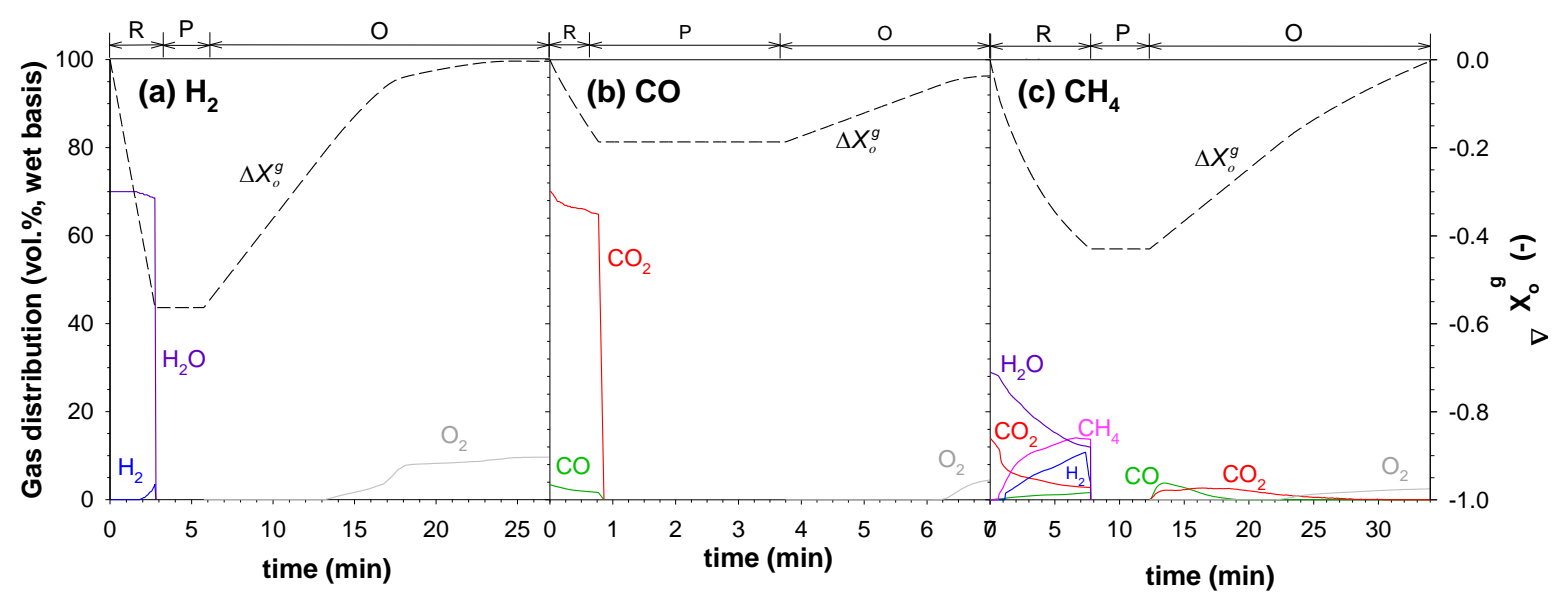

Figure 7. Gas distribution and variation in the conversion of $\mathrm{Mn} 77 \mathrm{Fe}[\mathrm{L} 4]$ oxygen carrier, $\Delta X_{o}^{g}$, for the spinel/mangano-wustite redox system (see reaction $\mathrm{R} 3$ as an example for $\mathrm{H}_{2}$ ) during the reduction at $950{ }^{\circ} \mathrm{C}$ in the fluidized bed with: (a) 50 vol. $\% \mathrm{H}_{2},+20$ vol. $\% \mathrm{H}_{2} \mathrm{O}$; (b) 50 vol. $\% \mathrm{CO}+20$ vol. $\% \mathrm{CO}_{2}$; (c) 25 vol. $\% \mathrm{CH}_{4}$, +10 vol. $\% \mathrm{H}_{2} \mathrm{O}$. Subsequent oxidation in air is also included. R: reduction; P: purge; O: oxidation. 


\section{List of Table captions}

Table 1. Summary of the Mn-Fe based oxygen carriers prepared for the screening process.

Table 2. Crushing strength, oxygen transport capacity and Rate index values for the materials tested in this work. 
1 Table 1. Summary of the Mn-Fe based oxygen carriers prepared for the screening process.

\begin{tabular}{|c|c|c|c|c|c|c|c|c|c|c|}
\hline $\mathrm{OC}^{(1)}$ & $\begin{array}{l}\mathrm{Mn}_{3} \mathrm{O}_{4} \\
\text { (wt.\%) }\end{array}$ & $\begin{array}{l}\mathrm{Fe}_{2} \mathrm{O}_{3} \\
\text { (wt. \%) }\end{array}$ & $\begin{array}{l}\mathrm{MnO}_{2} \\
\text { (wt.\%) }\end{array}$ & $\begin{array}{l}\text { Graphite } \\
\text { (wt.\%) }\end{array}$ & $\begin{array}{l}\text { Kaolin } \\
\text { (wt.\%) }\end{array}$ & $\begin{array}{l}\text { Sinter } \\
\text { Time } \\
(\mathrm{h})\end{array}$ & $\begin{array}{l}\text { g conditions } \\
\text { Temperature } \\
\left({ }^{\circ} \mathrm{C}\right)\end{array}$ & $\begin{array}{l}\text { Skeletal } \\
\text { density } \\
\left(\mathrm{kg} / \mathrm{m}^{3}\right)\end{array}$ & $\begin{array}{l}\text { Porosity } \\
(\%)\end{array}$ & $\begin{array}{c}\text { XRD } \\
\text { main phases }\end{array}$ \\
\hline $\mathrm{Mn} 77 \mathrm{Fe}[\mathrm{L} 4]$ & 76 & 24 & - & - & - & 4 & 950 & 5000 & 32.9 & $\mathrm{MnFeO}_{3}$ \\
\hline $\mathrm{Mn} 77 \mathrm{Fe}[\mathrm{M} 4]$ & 76 & 24 & - & - & - & 4 & 950 & 4992 & 31.2 & $\mathrm{MnFeO}_{3}$ \\
\hline $\mathrm{Mn} 77 \mathrm{Fe}[\mathrm{S} 4]$ & 76 & 24 & - & - & - & 4 & 950 & 4893 & 17.3 & $\mathrm{MnFeO}_{3}$ \\
\hline $\mathrm{Mn} 77 \mathrm{Fe}[\mathrm{L} 4+2]$ & 76 & 24 & - & - & - & $4+2$ & $950+1100$ & 5031 & 54.1 & $\mathrm{MnFeO}_{3}$ \\
\hline Mn77FeK[L4] & 60 & 20 & - & - & 20 & 4 & 950 & 4379 & 29.6 & $\mathrm{MnFeO}_{3}, \mathrm{Al}_{2} \mathrm{O}_{3}, \mathrm{SiO}_{2}$ \\
\hline $\mathrm{Mn} 77 \mathrm{Fe}\left[\mathrm{L} 4^{\mathrm{Mn}(\mathrm{IV})}\right]$ & - & 21 & 79 & - & - & 4 & 950 & 4843 & 44.9 & $\mathrm{MnFeO}_{3}, \mathrm{Mn}_{2} \mathrm{FeO}_{4}$ \\
\hline $\mathrm{Mn60Fe[L4]}$ & 58 & 42 & - & - & - & 4 & 950 & 4982 & 31.9 & $\mathrm{MnFeO}_{3}$ \\
\hline $\mathrm{Mn} 77 \mathrm{FeC}[\mathrm{L} 4]$ & 76 & 24 & - & 5 & - & 4 & 950 & 5004 & 41.9 & $\mathrm{MnFeO}_{3}$ \\
\hline $\mathrm{Mn} 77 \mathrm{FeC}[\mathrm{L} 12]$ & 76 & 24 & - & 5 & - & 12 & 950 & 5006 & 40.0 & $\mathrm{MnFeO}_{3}$ \\
\hline $\mathrm{Mn77FeC[L18]}$ & 76 & 24 & - & 5 & - & 18 & 950 & 4943 & 38.6 & $\mathrm{MnFeO}_{3}$ \\
\hline
\end{tabular}

(1) Nomenclature includes the Mn fraction, the particle size in raw materials and calcining time. For example, in Mn77Fe[L4]: 77 is $\mathrm{x}$ in the stoichiometry $\left(\mathrm{Mn}_{\mathrm{x}} \mathrm{Fe}_{1-\mathrm{x}}\right)_{2} \mathrm{O}_{3}$; L means a particle size of raw materials of $5 \mu \mathrm{m}(\mathrm{M}=2.6 \mu \mathrm{m}$ and $\mathrm{S}=1.9 \mu \mathrm{m}$ ); 4 is the calcining time at $950{ }^{\circ} \mathrm{C}$ (an additional calcining step for 2 hours at $1100{ }^{\circ} \mathrm{C}$ is described as $4+2$ ). In other materials, $\mathrm{K}$ and $\mathrm{C}$ mean that kaolin or graphite was in the formula, respectively.

(2) $\mathrm{MnFeO}_{3}$ and $\mathrm{Mn}_{2} \mathrm{FeO}_{4}$ represent bixbyite and spinel phases, respectively 
1 Table 2. Crushing strength, oxygen transport capacity and Rate index values for the 2 materials tested in this work.

\begin{tabular}{|c|c|c|c|c|c|c|c|c|}
\hline & \multirow{3}{*}{$\begin{array}{l}\text { Crushing } \\
\text { strength } \\
(\mathrm{N})\end{array}$} & \multicolumn{3}{|c|}{ Oxygen transport capacity $(\%)$} & \multicolumn{4}{|c|}{ Rate index $(\% / \mathrm{min})$} \\
\hline & & \multirow[b]{2}{*}{$R_{O C}^{o u}$} & \multirow[b]{2}{*}{$R_{O C}^{g}$} & \multirow[b]{2}{*}{$R_{O C}^{t}$} & \multicolumn{2}{|c|}{$\mathrm{CLOU}^{(1)}$} & \multicolumn{2}{|c|}{$\mathrm{CLC}^{(2)}$} \\
\hline & & & & & $\mathrm{N}_{2}$ & $\mathrm{O}_{2}$ & $\mathrm{H}_{2}$ & $\mathrm{O}_{2}$ \\
\hline $\mathrm{Mn} 77 \mathrm{Fe}[\mathrm{L} 4]$ & 2.7 & 3.0 & 6.6 & 9.6 & 0.30 & 1.1 & 12.2 & 8.4 \\
\hline Mn77Fe[M4] & 2.2 & 3.1 & 6.6 & 9.7 & 0.28 & 0.4 & 12.4 & 8.0 \\
\hline $\mathrm{Mn} 77 \mathrm{Fe}[\mathrm{S} 4]$ & 0.9 & 2.1 & 6.4 & 8.5 & 0.17 & 0.1 & 3.5 & 7.1 \\
\hline $\mathrm{Mn} 77 \mathrm{Fe}[\mathrm{L} 4+2]$ & 2.4 & 2.6 & 6.6 & 9.2 & 0.14 & 0.3 & 16.3 & 8.1 \\
\hline $\mathrm{Mn} 77 \mathrm{FeK}[\mathrm{L} 4]$ & 3.0 & 2.3 & 4.9 & 7.2 & 0.46 & 1.5 & 15.8 & 8.3 \\
\hline $\mathrm{Mn} 77 \mathrm{Fe}\left[\mathrm{L} 4^{\mathrm{Mn}(\mathrm{IV})}\right]$ & 0.8 & 2.1 & 6.4 & 8.5 & 0.20 & 0.1 & 12.4 & 8.5 \\
\hline Mn60Fe[L4] & 3.1 & 3.0 & 6.2 & 9.2 & 0.15 & 0.6 & 16.1 & 7.8 \\
\hline $\mathrm{Mn} 77 \mathrm{FeC}[\mathrm{L} 4]$ & 1.2 & 3.2 & 6.6 & 9.8 & 0.24 & 1.1 & 16.7 & 8.5 \\
\hline $\mathrm{Mn} 77 \mathrm{FeC}[\mathrm{L} 12]$ & 1.3 & 3.0 & 6.4 & 9.4 & 0.35 & 1.3 & 17.6 & 9.2 \\
\hline $\mathrm{Mn} 77 \mathrm{FeC}[\mathrm{L} 18]$ & 1.5 & 2.9 & 6.6 & 9.5 & 0.31 & 1.2 & 16.3 & 8.4 \\
\hline
\end{tabular}

(1) Cycles $\mathrm{N}_{2}$-air at $870^{\circ} \mathrm{C}$

${ }^{(2)}$ Cycles $\mathrm{H}_{2}$-air at $950{ }^{\circ} \mathrm{C}$ 3 